\title{
Za které životy netruchlíme? Uražení a ponížení v díle Judith Butlerové
}

\author{
When is Life Grievable? \\ The Insulted and Humiliated in the Work of Judith Butler ${ }^{1}$
}

\author{
Michal Rigel \\ Filozofická fakulta \\ Univerzita Hradec Králové \\ Rokitanského 62, 50003 Hradec Králové \\ michal.rigel@uhk.cz
}

\begin{abstract}
Abstrakt/Abstract
Úvodní část kritické stati stručně představuje autorku a prezentuje strukturu a obsah knihy Rámce války: za které životy netruchlíme?. Zohledněn je širší kontext a zvláštní ohled je věnován představení dosavadní publikační činnosti Judith Butlerové. Cílem je poukázat na to, že tematické zaměření a hlavní ideová východiska knihy mají v celém díle autorky nepopiratelnou kontinuitu. Následující pasáže se zaměřují na zprostředkování vybraných myšlenek více do hloubky, s důrazem zejména na rozbor autorčiny pozice k fenoménu my a oni a vztahu já $\mathrm{k}$ druhému. Kromě toho je pozornost věnována i konceptu rámování, v jehož osvojení tkví zvláštní význam pro porozumění hlavním autorčiným závěrům. Hlavní výhrady a polemika př́ležitostně prostupují celou prací, závěr poskytuje pouze shrnutí.
\end{abstract}

The introductory part of the critical essay briefly introduces the author and presents the structure and content of the book Frames of War: When is Life Grievable?. Special regard is given to the broader context, particularly to referring to other works of Judith Butler that have already been published. The purpose is to point out the fact that the thematic interest and ideological basis of the book are deeply rooted and have undeniable continuity across Butler`s work. The following passages aim to present selected ideas in more detail, with a special focus on the analysis of the author's position to the Us and Them phenomenon or

\footnotetext{
${ }^{1}$ Rád bych využil př́ležitosti připojit své uznání recenzentům, kteří beze stínu pochybnosti článek pozorně četli a poskytli mi $\mathrm{k}$ němu obsáhlé a zasvěcené komentáře. Ty mne $\mathrm{v}$ důsledku pomohly pohlédnout novým okem nejen na daný text, ale poskytly mi obecnější zpětnou vazbu ke způsobu mé práce. Poděkování za profesionální práci a odbornou péči při kultivaci závěrečné podoby textu zároveň zaslouží celý editorský tým časopisu.
} 
relation between Self and the Other. Besides this, attention is paid to the explanation of the concept called framing, in order to understand its particular importance for drawing key conclusions of the author. Major objections and reasons for disputation occasionally appear throughout the essay, the final part offers summary only.

„...I must say, I feel the reception of my work is none of my business. You know? It's not my concern. It's your concern. I just keep working. “

- Judith Butler (2007: 34)

\section{1. Úvod aneb o tomtéž pokaždé jinak}

Edice POLITEA nakladatelství Karolinum si klade za cíl představit českým čtenár̆ům publikace význačných politických teoretiků, jejichž práce dlouhodobě rezonuje v západním veřejném prostoru. Uvedení knihy Rámce války: za které životy netruchlíme ? $^{2}$ od Judith Butlerové (*1956) - americké filosofky, kulturoložky a světově uznávané teoretičky feminismu, queer a genderových studií - je v tomto ohledu zcela logickou volbou, naprosto v souladu s vytyčenou dramaturgií.

Hodnota publikace je o to větší, že se jedná o vůbec první knižní text autorky přeložený do českého jazyka. Ač byly některé její dřívější práce z velmi širokého tematického záběru, včetně např. psychoanalýzy, judaismu, politické filosofie, etiky, jazyka, literární teorie, teorie identity atd. dosud vydány v bezmála 30 jazykových verzích (např. patrně nejdůležitější Gender Trouble: Feminism and the Subversion of Identity - 1990), v českém jazykovém diskursu se s prací Judith Butlerové bylo možné seznámit pouze prostř̌ednictvím několika ad hoc přeložených textů, př́ípadně $\mathrm{z}$ děl sekundární literatury. ${ }^{3}$

${ }^{2}$ Butlerová, Judith (2013): Rámce války: za které životy netruchlíme? Přeložil Antonín Handl. Praha: Karolinum, 170 s. Pokud odkazuji na text v originálním znění, odkazuji na Butler, Judith (2009): Frames of War: When is Life Grievable? London, New York, NY: Verso, 193 s.

${ }^{3}$ V češtině dostupné autorčiny texty viz (Butler 1999; 2008; 2013; 2013a; či na podzim 2016 nakladatelstvím Karolinum připravovaný překlad knihy Bodies that Matter - Závažná těla). Ze sekundárních českojazyčných prací, popisujících, interpretujících či hodnotících dílo Judith Butlerové již jen namátkou a př́značně interdisciplinárně: kulturální studia (McRobbie 2006), performační studia/studia performativity (Pňačeková 2010; Matonoha 2010), literární studia (Culler 2015) a zejm. filosofie a feminismus (Šmejkalová-Strickland 1992; Barša 1999 a 2002; Fafejta 2001; Sokolová 2003; Nagl-Docekal 2007; Žižek 2007; Lišková 2009; Zábrodská 2009; Fulka 2002 a 2013). Za účelem komplexního zhodnocení osobnosti a díla v širším kontextu lze ještě rozhodně doporučit (Górská-Matonoha 2008). Pro čtenáře orientujícího se aktivně na česko-slovenský prostor se potom otevírají další možnosti, kromě např. (Kiczková 2007 aj.) je to zejména již více než dekádu existující překlad zmíněného manifestu de/konstruktivismu a zásadního mezníku v díle autorky Trampoty s rodom: Feminizmus a podrývanie identity, Bratislava, ASPEKT, 2003 (podruhé 2014). Vzhledem k vědomí tohoto „náskoku“ je proto 
Existující dluh bouřlivě diskutované, ale extenzivně citované a respektované autorce (mj. nositelka Ceny Theodora Adorna či ocenění Nadace Andrewa Mellona za mimořádný přínos pro humanitní vědy) se tak nyní začíná splácet, i když se značným zpožděním. V originále totiž byla recenzovaná kniha publikována již v roce 2009 v nakladatelství Verso, přičemž např. tato kritická stat', iniciovaná českým vydáním z roku 2013, vznikla až na přelomu let 2015/2016. Časový rozestup je navíc fakticky ještě větší, nebot' většina textů, ze kterých se kniha skládá, vyšla už dříve (byt' v částečně odlišné podobě); konkrétně pak mezi lety 2005-2008 v periodikách jako např. Society and Space; PMLA; British Journal of Sociology; differences). ${ }^{4}$

Dílo sestavené pro knižní vydání tvoří Úvod a pět samostatně fungujících kapitol, pojednávajících postupně o otázkách jako je Schopnost přežit, zranitelnost a afekt (3759); Mučení a etika fotografie (61-90); Sexuální politika, mučení a sekulární doba (91118); Nemyšlení ve jménu normativity (119-140) a Požadavek nenásilí (141-164). Jednotlivé oddíly tvoří koherentní celek v tom ohledu, že odkazují k různým aspektům tzv. války s terorem. Právě volba ,válečné problematiky“ může být do určité míry překvapením, na druhou stranu u Judith Butlerové - coby globální intelektuálky, která své názorové postoje prezentuje $\mathrm{v}$ mnoha různých oblastech - je už téměř zvykem, že $\mathrm{s}$ každou další knihou otevírá nové téma nebo alespoň aktualizuje a reformuluje starší, v rámci kterého diskutuje zcela odlišné otázky.

A to platí beze zbytku i v prrípadě recenzované knihy. Úvod (s. 9-35), jenž seznamuje čtenáře se základními ideovými východisky a definuje klíčové pojmosloví

symbolické, že i doslov k recenzované knize je proveden filosofkou a feministkou Lubicou Kobovou $\mathrm{v}$ její rodné slovenštině. Ten je užitečný $\mathrm{v}$ tom ohledu, že nabízí zasvěcený a do kontextu zasazený komentáŕ k hlavním sdělením knihy, ač mezi jiným např. odkazuje i na „precízne zhrnutie a kritiku sporov liberálov vo veci spravedlivej vojny“ (s. 158), kterým by mohla být jedině pasáž, kde se autorka vyjadřuje k polemice T. Asada a M. Walzera (s. 131136), jež sice zachycuje jeden aspekt současných diskusí, ovšem nenaplňuje moji představu precizního shrnutí sporů, které se dnes vedou uvnitř tradice úvah o spravedlivé válce (možná snad explicitní přihlášení $\mathrm{k}$ osobitě definovanému požadavku nenásilí - s. 141-156 - lze traktovat jako prríspěvek $\mathrm{k}$ širším debatám o etice použití násilí).

${ }^{4}$ Podrobné zastavení u vročení zde není provedeno náhodou, poněvadž odhaluje fakt, na který vzhledem $\mathrm{k}$ tematickému zaměření práce není nezajímavé upozornit: všechny eseje byly původně vypracovány v průběhu funkčního prezidentského období George W. Bushe, jehož administrativa se svými kroky v zahraniční a bezpečnostní politice nepochybně představovala významný podnět pro jejich napsání (napřs. s. 40, 48, 62, 84-85 aj.). Je potom symbolické, že konečná knižní podoba, složená z jednotlivých esejí, byla hotova až krátce po nástupu Barracka Obamy do úřadu prezidenta USA (který mimochodem zase měl v době dokončení tohoto hodnocení za sebou poslední vystoupení s výroční zprávou o stavu unie a pozvolna se chystal do prezidentské emeritury). Ač by vzhledem k této opožděné reflexi dnes již bylo možné zodpovědět řečnickou otázku Judith Butlerové z úvodu knihy (s. 8) „k jakým konkrétním zlepšením při řešení válečných konfliktů během jeho (Obamova - pozn. MR) mandátu dojde“, ponechme to budoucím pracím autorky samotné a přejděme pro tentokrát $\mathrm{k}$ představení $\mathrm{a}$ evaluaci obsahu publikace. 
nezajištěného života a života hodného truchlení, dává jasně na srozuměnou, že v knize jde $\mathrm{v}$ podstatě o pokračování projektu z oblasti morální a politické filosofie, který autorka započala již ve svém díle Precarious Life: The Powers of Mourning and Violence (2004). Tam poprvé předkládá k podrobnému zkoumání pojem nezajištěného života $^{5}$, aby později pokračovala v otázkách souvisejících se statusem subjektu obecně ve svém Giving an Account of Oneself (2005; či předtím Butler 1997) nebo analýzou mocenských vztahů v rámci instituce státu a mimo ni, tzv. „opuštěné životy, nacházející se vně polis“ (Butler 2013b, s. 20-21) v Who Sings the Nation State? (Butler - Spivak 2007). Navíc myšlenkové zdroje základních premis z Rámců války je možné sledovat ještě hlouběji v jejím díle.

Mezi věčná témata Judith Butlerové patří např. jazyk, moc či identita aj. Kromě využití (srov. zneužití? viz Schwartzman 2002) teorie řečových aktů J. L. Austina (2000) se trvale odvolává na teorie moci M. Foucaulta (1982; 1999; 2000, srov. Hennessy 1995) nebo dekonstrukci v pojetí J. Derridy (1993; 1999; 1999a). Spektrum autorů, kteří vytváří intelektuální zázemí autorky a jejichž dílem se inspiruje, je pochopitelně mnohem širší (např. L. Althusser, S. Freud, G. W. F. Hegel, L. Irigaray, J. Kristeva, J. Lacan, E. Lévinas, F. Nietzsche aj.). Často přitom platí, že jejich myšlenky přizpůsobuje novým účelům, osobitě je interpretuje nebo s nimi v zásadních bodech polemizuje. I přes primární zaměření raných knih (zejm. 1990 či 1993) na oblast gender studies a feminismu zde tedy existuje zřetelná vazba s hodnocenou knihou.

Není cílem této kritické stati zhodnotit zevrubně celé dosavadní dílo autorky, přesto se jeví důležité zmínit některé klíčové argumentační figury ze starších knih a

\footnotetext{
${ }^{5} \mathrm{~S}$ pojmem „precarious life“ operuje ve velké míře i recenzovaná kniha, přičemž v jejím českém překladu není termín pouze mechanicky převeden jako „,prekarizovaný život“ (či snad „prekérní život“" viz Heczková 2013, s. 6), ale jako „,nezajištěný život“ (konsekventně se toho držím i zde). Překladatel $\mathrm{k}$ tomuto rozhodnutí dospěl i přesto, že např. v př́ípadě ,precarious work“ se v českém jazyce ujalo spíše používání „,prekarizovaná práce“. V knize ovšem vystupuje také pojem „,prekarita“, to když se překládá z originálu termín „precarity“ (ač i zde jsou výjimky, viz např. s. 10, orig. 2). Oproti tomu „precariousness“ je již znovu „nezajištěnost“. V př́padě obou pojmů lze hovořit o navzájem propletených konceptech jak jazykově, tak obsahově, viz (s. 27-35). Z hlediska překladatelské práce na českém vydání je možné vyzdvihnout za všechny ještě jeden moment, konkrétně obsažen přímo v názvu knihy. Ten zní v originálu takto - Frames of War: When Is Life Grievable? - a nese s sebou význam, který by bylo skutečnou výzvou dovedně převést $z$ anglické do české verze i se všemi nuancemi. Slovo „frame“ tj. ,rám“ nebo „rámec“ (zejm. ve smyslu okruhu působnosti) a jeho pasivní slovesná forma „to be framed“ tj. „být za/rámován“ má totiž v angličtině ještě další významy jako např. „být obviněn“ a to včetně obvinění falešného a nespravedlivého („frameup“), které zahrnuje vědomé zacházení s důkazy způsobem, jenž nezpochybnitelně vyvolá dojem obvinění objektivně pravdivého, prakticky vylučujícího možnost ,viníka“ se obhájit (s. 15 a 17); řečeno hezky česky: ušili to na něj aneb komplot. Oba významy „rám(c)ování“ (jakožto klíčového konceptu přítomného napříč dílem - s. 168) v knize hrají svoji roli, at' už jde o ten, který má obsáhnout a určit, co je viděno, tak i ten odkazující k mocenské manipulaci s tím, co se jeví.
} 
poukázat na jejich přítomnost $\mathrm{v}$ pozdějších textech, včetně toho zde recenzovaného. Možnost provést dlouhé ,přemostění“ demonstruje určitou konzistenci a kontinuitu usilování Judith Butlerové, bez ohledu na rozličná témata, která si jako autorka volí za náměty svých publikačních výstupů. Základem toho, co mělo na začátku 90. let na feminismus významný formativní, ba přímo paradigma-proměňující vliv, je v podstatě důsledné promyšlení myšlenky Simone de Beauvoirové, slavně parafrázované jako „ženou se člověk nerodí, ale stává“ (1966, srov. Butler 1986). Tato replika, která je ovšem u Judith Butlerové platná i pro rodovou kategorii mužů, již jsou stejně tak výsledkem určitého procesu formování, byla $\mathrm{v}$ jejím díle rozvedena a složitě argumentačně obhajována, ${ }^{6}$ aby tím později získala obecnější rozměr a vystoupila za hranice svého oboru.

A tak jestliže autorka předkládá kontroverzní tezi, v níž tělo a pohlaví přestávají být nezpochybnitelnými vrozenými anatomickými danostmi a stávají se spíše sociokulturními konstrukcemi a jestliže v tomto důsledku napadá binární chápání pohlavní (potažmo genderové) identity jako biologicky podmíněné, stabilní a neměnné kategorie,

\footnotetext{
${ }^{6}$ Maximálně stručně řečeno autorka odmítá gender coby stálou identitu a nutný výsledek biologické predestinace dané pohlavím (které zase bývá určeno tělesnou schránkou). Místo toho zastává názor, že genderová identita se konstituuje performativně (z angl. to perform: vykonat, předvést, představit, vytvořit), tj. sérií ritualizovaných opakovatelných aktů, jež vytváří efekt její stability. Gender tak lze považovat za performativní v tom smyslu, že nepředstavuje cosi, čím by člověk byl od základu (zde dochází k popření existence skupinově sdílených esenciálních rysů), ani to, čím ho kdosi stvořil (jakýmsi výsledkem), ale raději to, co člověk sám dělá (a tím je re-signifikační proces, jakési stávání se: každodenní hromadné opakování určitého jednání sice obligatorní a dozorované mocenskými mechanismy, které jej manipulují, ale nikoli jednosměrně, nebot' samy jím mohou být transformovány; detailněji ke vztahu subjekt - moc a procesu subjektivizace viz Butler 1997). Kategorie genderu nejsou nezvratné a opírající se o jakousi metafyzickou realitu per se, nýbrž jde o něco nezávisle konstruovaného a generovaného $\mathrm{v}$ průběhu času v rámci diskursu daného společenství. Lehce posunuta tak byla teze poststrukturalistů, že subjekt je vytvořen diskursem, který jej domněle objektivně popisuje, čímže způsobem však ve skutečnosti subjekt vytváří (neboli diskurs, ,je praktikou systematicky vytvářející objekty, o nichž mluvi““ - Foucault 2002, s. 78-79). Pokud ovšem gender není ustaven kulturní interpretací, vycházející z prediskursivního a objektivně existujícího pohlaví, je destabilizována i samotná pozice pohlaví, jakožto zakladatele tohoto zdánlivě apodiktického a prrirozeného řádu. A skutečně postulát Judith Butlerové (1990, s. 112) zní: „i kategorie pohlaví je genderovou kategoriî" a výslednicí určitého dynamického diskursu, pročež nemáme žádný důvod očekávat, že pohlaví jsou fixně a nezaměnitelně právě dvě - mužské a ženské. Takový předpoklad by totiž vlastně sám produkoval to, co by původně anticipoval, což je i př́ípad společenské normy o heterosexuální orientaci (tzv. heteronormativita), která je opět založena na tom, že svou normativitu nepřiznává a předstírá reálný, biologicky zakotvený a přirozený charakter (tzv. naturalizace norem). Jde o relativně složitou (jedna z mnoha interpretací viz např. Salih 2002) a pochopitelně i o dosti radikální re-formulaci problematiky, která, dochází-li $\mathrm{k}$ promyšlení všech prvků do důsledků, bývá namnoze označována za značně kontroverzní teorii. Nelze se proto divit, že se záhy stala námětem pro řadu nesouhlasných a polemických reakcí, jež kritizovaly východiska či závěry Judith Butlerové z velmi rozmanitých důvodů a úhlů pohledu, viz např. (Ebert 1995 a 1996; Nelson 1999; Beste 2006; Boucher 2006; Hawkesworth 2006, s. 145-175) aj.
} 
činí tak mj. proto, aby zamezila definitivním závěrům o heterosexuální orientaci a snaze sociálně stigmatizovat a patologizovat veškeré ne-heterosexuální praktiky. Vynucování společensky artikulované genderové normativity, vydávané za ontickou, vedlo podle Judith Butlerové ve svém důsledku $\mathrm{k}$ násilí (at’ už fyzickému, legislativnímu či „vědeckému“, tj. např. různé lékařské, zejm. psychiatrické diagnózy) na homosexuálech, lesbách, transsexuálech, hermafroditech a dalších osobách, které s touto zprostředkovanou normou nebyly konformní.

V knize Rámce války jsou namísto těchto aberantních, ba „deviantních“ podob pohlaví, genderu a sexuální orientace, tzn. lidí, kteří nenaplňují přípustné role v daných oblastech, za „neuznané“ a „nezajištěné“ považovány životy části muslimské populace (s. 44 či 110), nelegálních a islámských imigrantů do „prvního světa“ (s. 41 a 97), vězněných v Guantánamu (s. 56), mučených v Abú Ghrajbu (s. 70) aj. Jádro zájmu je ale u autorky shodné: opět zkoumá, za jakých podmínek a jakým způsobem dochází k vyloučení některých způsobů existence a poukazuje na nebezpečí nezahrnutí vybraných individuálních subjektů do ,rámů“ (s. 13-18) ,životů hodných žitî“ (s. 25; termín ostatně použit již v Butler 1993, srov. Agamben 2011, např. s. 135-141 aj.). A právě zranitelnost, nezajištěnost a vysoká míra alokace prekarity u těchto odmítaných a marginalizovaných skupin vede $\mathrm{k}$ hluboké a komplikované meditaci o podmínkách a politických opatřeních, za kterých by násilí vznikalo s menší pravděpodobností, „životy byly brány na vědomí“ a „spravedlivěji hodné truchlení“ (s. 10-12, resp. 19-21).

Vysvětlení toho, proč je soustavně artikulované téma „uražených a ponížených““ v díle Judith Butlerové tentokráte uchopeno specificky v kontextu válečné situace je potom nasnadě. Rozdělení na kategorie legitimních subjektů na jedné straně a vyloučených, méněcenných, kulturně a společensky nesrozumitelných bytostí, tzv. „,neosob“ (s. 24) na straně druhé, se totiž stává nejnaléhavější právě v situaci války, kde jsou druzí jmenovaní vystaveni zvlášt’ zvýšenému riziku. Slovy autorky: „válka je vzorovým př́kladem minimalizace nezajištěnosti pro jedny a její maximalizace pro druhé“" (s. 53).

\section{My a oni ve válce, resp. životy truchlení hodné a truchlení nehodné}

Zastavme se proto nyní u války (v daném případě tzv. války s terorem) jako situace, na kterou reagují všechny sesbírané eseje, tvořící jednotlivé oddíly knihy. Téma války v obecném smyslu je tématem extrémně komplexním a obsahuje obrovské množství elementů ke zkoumání; proto i spektrum témat, které jsou předmětem pojednání $\mathrm{v}$ jednotlivých kapitolách knihy, je tolik široké. Nicméně nakonec lze ve válce (jakožto i v obsahu všech kapitol knihy) identifikovat všudypřítomnost jednoho fenoménu (na který se zjevně zaměřuje i autorka). Ten tvoří v konfliktech, ve kterých po určitou dobu dochází k organizovanému použití vysoké intenzity síly a násilí na kolektivní úrovni tj. ve válkách - esenciální složku a nemůže z principu chybět v žádné takto definované 
události. Tento inherentně př́tomný jev lze označit jako dichotomii „my a oni“, potažmo fenomén ,toho druhého“. 7

V případě polarity „my a oni“ jde skutečně o koncept, jenž se zdá pro porozumění některým aspektům kolektivního násilí a války klíčový. Tato dualita zjednodušeně řečeno pracuje s předpokladem, že mezi lidmi lze rozeznat celou řadu dělicích linií např. na úrovni rasy, etnicity, jazyka, třídy, věku, náboženství atp., které dále umožňují jejich rozdělení na základě příslušnosti k některé z nich. Sociologové, antropologové, sociální psychologové, filosofové a kognitivní vědci (vyberme reprezentanty tří odlišných generací, např. Sumner 1906; Tajfel 1974 či Tajfel \& Turner 1986; Green 2013, zejm. s. 19-104, srov. Haidt 2012, s. 219-255) přitom na základě mnohých pozorování a experimenti̊ opakovaně ukázali, že za určitých podmínek vzniká silná identifikace s vlastní členskou skupinou (tzv. in-group), doprovázená často negativním vymezením vůči cizí skupině (tzv. out-group). To je úzce svázané s etnocentrismem, tj. universálně přítomným přesvědčením (viz seznam kulturních universálií - Brown dle Pinker 2002, s. 435-439) o tom, že vlastní skupina je celkově nadřazena jiným skupinám i se všemi konsekvencemi, které z takového př́stupu vyplývají, viz např. (Parker 1994, s. 40-58 nebo Tilly 2003 aj.).

I autorka se v knize antagonismem „my a oni“ zabývá a předkládá analýzu toho, co konkrétně se s ním děje v době války. Za nejjednodušší způsob, jímž lze efektivně nahlédnout dělicí linii mezi skupinami lidí, která působí jako hranice na ose „,my a oni“, přitom považuje právě zkoumání, čí životy jsou oplakávány a čí jsou naopak shledány nehodnými truchlení (,ze strany těch, kdo vedou války v zájmu zachování životů a společenství, těch, kdo je chtějí bránit proti životům jiným i za cenu ničení těchto životů, je toto rozdělení světa zjevné“ - s. 41). Skutečnost rozdílné distribuce veřejného truchlení tak představuje pro Judith Butlerovou velmi podstatnou politickou otázku a výzvu k tomu, jak uchopit „my“ v globální rovině a zjistit, kdo všechno je do této kategorie spolu s námi zahrnut a v jakém rozsahu může být člověk př́ipadně odpovědný za „ty druhé“. 8 Pokud se totiž identifikuji s nějakou skupinou na základě např.

\footnotetext{
${ }^{7}$ Srov. antropologické zkoumání společností Inuitů či některých severoamerických indiánů, kde rozměr skupinového násilí zcela absentoval (Benedictová 1999, s. 36-38). I tam ovšem fungoval ještě nižší společný jmenovatel než ,my a oni“ a to konkrétně „ten druhý“, do nějž lze zahrnout a dále dle něj interpretovat konflikty s použitím násilí na rovině individuální k odlišnému chování člověka, který je součástí většího celku v porovnání se situací, kdy vystupuje sám za sebe, viz (Tajfel 1979) a jeho klasifikace meziskupinového a interindividuálního chování.

${ }^{8}$ Na jedné straně autorka zastává názor, že odpovědnost za druhé by měla přesahovat hranice
národního státu, protože dnes je to právě toto politické uspořádání, které nejčastěji vystavuje své
populace násilí (s. 29), ovšem zároveň horuje proti imperialismu, který by si nárokoval
suverenitu za vlastními hranicemi. Nelze se přitom zbavit dojmu, že odkazuje kjedné ze
zásadních problémových otázek ohledně tzv. humanitární intervence, tj. zdali je
ospravedlnitelné intervenovat v zemi, kde dochází k hrubému, systematickému a rozsáhlému
} 
národnosti, území, jazyka nebo kultury, a pokud na tomto základě odvozuji určitou odpovědnost ve vztahu $\mathrm{k}$ dané komunitě, tak se podle Judith Butlerové implicitně hlásím k odpovědnosti jen za ty, kteří jsou mi nějakým způsobem „rozpoznatelně podobní“ (s. 39).

Z takové teze pochopitelně nutně vyplývají další otázky, z nichž mnohé autorka při následném důkladném promýšlení problematiky skutečně klade. Níže se pokusím představit její postoje ke dvěma základním, jejichž adresování - často pomocí ilustrace na vybraných epizodách války s terorem - představuje po mém soudu nejpodstatnější část knihy. Zaprvé: jaké „rámce rozeznatelnosti““9 jsou ve hře, když považujeme někoho za sobě podobného (a čím se vlastně řídí pravidla a zásady pro „,podobnost“?). A zadruhé: jaká je naše odpovědnost vůči těm, kteří skončí vně a vůči těm, které neznáme a kteří jsou daleko od nás ${ }^{10}$ (v tomto ohledu se potom zdají být skupiny obyvatel, které se nejvíce vzpírají současným normám „podobnosti“ a vymykají z rámců „rozeznatelnosti-uznatelnosti“ a „,srozumitelnosti“ největší zkouškou našeho smyslu pro

porušování lidských práv, nebo je neakceptovatelné a potenciálně nebezpečné vměšovat se do vnitřních záležitostí zemí a je třeba respektovat teritoriální suverenitu? Tvrzení, že „není snadné tyto dvě věci rozlišit a jedná se o naléhavou výzvu dneška“" (s. 48) ovšem nepředstavuje žádný průlom v argumentaci mezi zastánci obou konceptů mezinárodní bezpečnosti. Ke smělejším snahám, jak se vypořádat s tímto dilematem, viz např. (Holzgrefe - Keohane eds. 2003 nebo Shue 2008, příp. další texty z téhož tematického vydání Filosofického časopisu).

${ }^{9}$ Anglický termín „recognizability“ je v této pasáži (s. 39) překládán jako „rozeznatelnost“, ale jeho obsah v podstatě odkazuje $\mathrm{k}$ tomu samému pojmu, jenž je dříve v knize překládán jako „uznatelnost“" (podrobněji prredstaven viz s. 12-14). Překladatel patrně provedl tuto terminologickou distinkci na základě autorčina vlastního odchýlení od pojmosloví, ke kterému ovšem došlo bez zřetelného sémantického posunu: na s. 13, orig. 5 se hovoří o „,frames of recognition“" a na s. 39, orig. 36 už „frames of recognizability“. V českém vydání potom čteme „rámy uznání“, resp. „rámce rozeznatelnosti“ (zde by mohl následovat dotaz, proč je „frames“ na mnoha místech knihy převedeno jako „rámy“ a na řadě jiných jako „rámce“, ale to by byl jen další příspěvek do př́běhu nejednotného názvosloví ohledně pojmu „framing“ v českém akademickém diskursu mediálních studií, viz: zarámování - Trampota 2006; rámcování Kalvas et al. 2012; rámování - Giles 2012, aj.

${ }^{10}$ Př́ínos k problematice možného rozšǐření množiny subjektů, na které se vztahuje etický apel, provedl v minulosti již např. (Lecky 2007, příp. Singer 2011, jenž poskytuje další vysvětlení fenoménu „rozšiřujícího (či rozpínajícího) se kruhu“ morálního zájmu směrem od úzké prŕibuzenské skupiny až k celým populacím). Druhý jmenovaný autor trvale obhajuje pozici, která stojí na předpokladu, že rozšiřující se záběr etického rámce klade požadavky na jednání jednotlivce směrem ke stále většímu počtu osob, včetně těch, se kterými není aktér $\mathrm{v}$ bezprostředním osobním spojení. Existence vzdálenosti čítající i několik tisíc kilometrů je totiž bezvýznamná vzhledem k morálnímu závazku pomoci druhému člověku, zvláště pokud existuje disproporce mezi úsilím, případně „,enou“, kterou musí donor vynaložit, a obrovským potenciálním užitkem recipienta. Jedním z dalších důvodů je i faktická relativizace vzdálenosti, způsobená rozvojem technologií a odvětví komunikace, výpočetní techniky, dopravy aj., která ze světa činí „globální vesnici“ se silným imperativem naší globální odpovědnosti. Jinými slovy: ,jak se svět zmenšuje, naše kapacita pro efektivní morální jednání roste“ (Singer 1997). 
sounáležitost, neboli máme-li vůbec nějakou odpovědnost za druhé, nevztahuje se nakonec jen na některé druhé? - s. 39).

\section{1 „Život každého jedince je do jisté míry vždy v rukou druhých““}

Při zodpovídání těchto otázek a hledání vztahu mezi entitami označovanými jako „my a oni“ vychází autorka z postulátu „zobecněné nezajištěnosti““ (s. 37), tj. poměrně triviálního konstatování, že neexistuje život bez závislosti na širších sítích společenských vztahů, ani život, který by překonal zranitelnost a smrtelnost. Všechny životy jsou z principu nezajištěné v tom smyslu, že jejich přetrvání není nijak zaručeno: mohou být zničeny, at' už vědomě nebo následkem nehody (s. 28-29). Fakt, že každé tělo je potenciálně ohrožené druhými (všichni máme moc ničit a možnost být zničeni) ${ }^{11}$ podle Judith Butlerové způsobuje, že subjekt, kterým jsem já, je takto vázán na subjekt, kterým nejsem (s. 45). Disponování touto mocí tvoří pevné pouto mezi námi všemi, definuje naši nezajištěnost a zdánlivě vytváří - ale ve skutečnosti spíše v mnoha ohledech oslabuje - kontrapunkt „my a oni“. Jestliže moje schopnost přežít závisí na vztazích k těm druhým - k vám, bez kterých nemohu existovat - pak má existence není jen má, ale nachází se mimo mě, v řadě vztahů, které podle autorky předchází a předurčují hranice toho, kým bych měl být já (s. 19 a 46).

Autorka tímto způsobem poukazuje na skutečnost absurdity představy o antagonistických konfliktech hry s nulovým součtem, když „mé“ já přece není bez života druhého vůbec myslitelné a snaha o jeho anulaci by pouze konsekventně vedla $\mathrm{k}$ anulaci vlastní. ${ }^{12}$ Zároveň upozorňuje na to, že etický problém, zda se dopouštět

11 Základ myšlenky o zobecněné nezajištěnosti subjektu, kterou autorka rozvíjí, má svůj předobraz $\mathrm{v}$ mnohem starších dílech, když stojí u základů některých významných koncepcí politické filosofie, viz např. všeobecně známý postřeh Thomase Hobbese (2009, s. 87): „Přríroda vytvořila lidi natolik rovnocennými ve schopnostech těla a mysli, že i když je jeden člověk někdy očividně tělesně silnější nebo duševně bystř̌jší než druhý, přesto když se shrne všechno dohromady, není tento rozdíl mezi jedním a druhým člověkem natolik závažný, aby si na jeho základě mohl jeden člověk nárokovat jakoukoli výhodu, kterou by si obdobně nemohl nárokovat někdo jiný. Jde-li totiž o tělesnou sílu, má i ten nejslabší dosti sil, aby zabil nejsilnějšího bud' tajnými intrikami, nebo ve spojení s jinými, kdo jsou ve stejném nebezpečí jako on sám.“

${ }^{12} \mathrm{Ve}$ výše prezentovaných úvahách, že když zničím druhého, zničím vlastně toho, na kom závisí mé př̌žití, a tak svým destruktivním činem vlastní já ohrožuji (nebot' jak bylo řečeno: „mé“ já není bez vašeho života myslitelné), se autorka inspiruje psychoanalytičkou Melanií Kleinovou (jakkoliv volně a polemicky to činí: „způsob, jakým tu Kleinovou cituji, je úmyslně nekleinovský“ - s. 46; doslovně by podle Melanie Kleinové na druhém člověku vlastně nezáleželo pro něj samého coby osoby, které já, nezávisle na čemkoliv dalším, přiznám právo na život, nýbrž ono uznání by představovalo instrumentální jednání, motivované sebezáchovou - neboli: zajištuji přežití druhého jen jako prostředek směřující $\mathrm{k}$ účelu, abych přežil já sám). Kromě Melanie Kleinové si autorka při hledání cest k omezení destruktivních sklonů ve vztahu k druhému bere na pomoc známou etickou koncepci filosofa Emmanuela Lévinase (1997, s. 163-225 nebo 2009, s. 208-214), označovanou jako „setkání s tváří“ (vhodná sekundární literatura $\mathrm{k}$ tomuto chef-d’oeuvre např̀ viz Llewelyn 1995 a Peperzak 2005). V této koncepci se 
násilí, či nikoli, se pochopitelně objevuje pouze ve vztahu k druhému, který figuruje jako potenciální objekt zranění. Na jednu stranu bychom mohli číst tuto výzvu chápat druhou osobu neodděleně od vlastního já coby argumentační podložení dobře známé formule „miluj bližního svého jako sebe samého“, opakované na mnoha místech Starého i Nového zákona, prrípadně i jako paralelní přihlášení se ke konceptu ne-Já v buddhismu (zejm. Collins 1982 či stručněji Williams \& Tribe 2011, s. 64-70) a obecněji k iluzornosti jáství v dalších východních filosoficko-náboženských směrech. Nenásilí, které by takové hledisko (tj. schopnost cenit si zájmů druhých na úrovni svých vlastních) implikovalo, by ovšem byla pouze jedna strana mince.

Popření existence druhého totiž může mít kromě jakéhosi organického pojetí vzájemné závislosti i další rozměr, na který autorka spíše poukazuje: „není-li tu žádné „ty“, nebo je nelze slyšet ani vidět, není zde žádný etický vztah“ (s. 154), který by zaručil základní standardy v zacházení. ${ }^{13}$ Ono „ty“ podle Judith Butlerové chybí zejména tehdy, když si obě strany odmítají uvědomit, že jsou jakkoliv zahrnuty v pozici „té druhé“. Etické imperativy a určitá garance „neodstranitelnosti života“ zkrátka existují pouze v identifikaci vztahu mezi osobami uvnitř rámů, ve kterých se pohybují životy hodné žití. Přitom

maximálně stručně tvrdí, že na tvář druhého je vznášen požadavek etické reakce, který je dán každodenním setkáváním, uvědoměním si vzájemné podobnosti a rozpoznáním sebe sama $\mathrm{v}$ druhém. Právě to má následně vyvolat zpochybnění vlastní libovůle a reciproční uznání. Interpretace Judith Butlerové (zejm. s. 147-152) zní tak, že tvář a její bezbrannost je stimulem k „pokušeni““ použití násilí, které může subjekt cítit ve styku s „nezajištěným“ životem druhého. Tváŕ v Lévinasově koncepci by tak podle autorky nedávala smysl bez vražedného impulsu („,vyzývá k zabití“), proti němuž je ale třeba ji bránit (,zároveň je i jeho zákazem“), což implikuje, že se jako lidé pohybujeme v následující ambivalenci: máme touhu zabíjet a etickou nutnost tak nečinit. Zde je nicméně třeba podotknout, že Emmanuel Lévinas v jiných dílech tematizuje i rozměr možného použití násilí $\mathrm{k}$ druhému, viz (1994; 1998 a 2006), přičemž podle některých autorů jej neshledává zcela neslučitelným se svojí etickou teorií, viz (Altez 2007 či Atterton 2009, srov. Tahmasebi-Birgani 2014, př́íp. Alford 2001) aj.

${ }^{13}$ I v minulosti lze uvést nespočet př́ikladů, kdy popření lidskosti u druhého resultovalo $\mathrm{k}$ výše zmíněnému odepření „standardu na zacházení“ známého např. z označení za pohany v případě křest’anů, góje v případě Židů či barbary v př́ípadě Řeků (slavně viz Aristoteles 2009, s. 38-39, tj. 1252b a důsledky, které z toho plynou, viz rozdíl mezi válkou - polemos - a (občanským) rozbrojem - stasis - Platon 1997, s. 13, tj. 628b nebo Platon 2014, s. 218, tj. 470c, př́íp. komplexněji 216-219, tj. 469b-471c) aj. Podobný „dvojí metr“ v zacházení k určitým skupinám, obhajovaný z rozmanitých pozic, lze identifikovat i v dílech mnohých dalších od Cicera, Erasma Rotterdamského, Alberica Gentiliho nebo Johna Stuarta Milla (dle Tuck 2001, s. 10-11, resp. 29-30, 34-36; Mill 1859). Ze sekundární literatury se komplexněji vyjadřují k problematice ještě např. texty Doing Justice to Others (Neff 2014, s. 9-49) nebo Culture, the Enemy and Moral Restraints of War (Coates 2006, s. 208-221), srov. (Grimaldi 2013, prríp. Balibar 2015). Jako výstižná tečka za touto odbočkou může posloužit Theodorem Adornem (2009; 2010) a Maxem Horkheimerem inspirovaný citát autorky: „násilí ve jménu civilizace odhaluje její vlastní barbarství, jakkoliv se snaží „obhajovat“ vlastní násilné jednání předpokládanou barbarskou ne-lidskostí druhého, proti němuž násilí uplatňuje“ (s. 84). 
„má-li ke mně požadavek druhého dosáhnout, musí být nějakým způsobem zprostředkován, což znamená, že sama naše schopnost reagovat nenásilně (...) závisí na rámech, $\mathrm{v}$ nichž se klade svět a jimiž je vymezena oblast jevení“"(s. 152).

A právě z možnosti subjektu dostat se mimo rámy uznatelnosti - a všech negativních konsekvencí, které to přináší - podle Judith Butlerové vyplývá, že kritika násilí musí nezbytně začít otázkou po reprezentovatelnosti života (přihlášení se k nenásilí, zdá se, vyžaduje vést neustálý

„zápas o jevení a o smysl, tázaje se, jak nejlépe uspořádat média za účelem překonání rozdílných způsobů, jimiž se život nahlíží jako hoden žití nebo jako žitý život, a způsobů, kterými jsou některé životy ohodnoceny jako hodné truchleni““" (s. 154).

\section{2 „Rámy jsou mocenské operace“}

Proces diferenciace (autorkou označovaný jako rámovánî), který ustavuje životy, jejichž ztracení by bylo hodno truchlení a jejichž ztracení by truchlení hodno nebylo, funguje na principu jakési mřřžky forem pozornosti (samozřejmě nikoliv apriorní - rámy nejsou statické nebo nezměnitelné), využívající selektivních prostředků ke konstituování žitého života s nárokem jeho uznatelnosti, potažmo oplakávatelnosti. ${ }^{14}$ Jde přitom o konstituci pomocí vylučovacího procesu, během něhož jsou označeny skupiny subjektů, jež

,je možné postrádat nebo mohou být odstraněny, právě protože jsou rámovány jako již ztracené nebo odstraněné; jsou prezentovány spíše jako hrozba pro lidský život, jak jej známe, než jako žijící populace, které vyžadují ochranu před nelegitimním násilím“" (s. 33).

Jedině důsledná analýza mechanismů, jež dávají vzniknout nerovnému uznání nezajištěnosti - o což se právě autorka zkoumáním rámování v knize pokouší - může

\footnotetext{
${ }^{14}$ Jako jeden z prvních položil akcent na způsob, jímž jsou zpravodajské informace a určité aspekty vnímané reality vybírány a prezentovány publiku, neboli „rámovány“ (tj. v širším významu: úhel pohledu, kontext, volba výraziva, titulku, tónu a ilustrativních př́íkladů nebo odkazování na zdroje, selekce a celková interpretace izolovaných faktů či různé další stylistické a textové či mimotextové prvky), americký sociolog Erving Goffman (1974; event. Bateson 1972). Od té doby se fenoménu, který má pomocí různých nástrojů a za účelem sledování různých cílů schopnost „,definovat problémy, diagnostikovat prŕččny, vytvářet morální soudy a navrhovat nápravy“ dostalo náležité pozornosti, viz např. (McQuail 2009, zejm. s. 389-391 a 526-527; McCombs 2009: zejm. s. 131-147 aj.). Autorka tedy v souvislosti s průzkumem taktiky rámování informací médii po 11. záŕí 2001 a během tzv. války s terorem (srov. Tumber \& Palmer 2004 či Reese \& Lewis 2009) svojí částí přispívá ke studiu toho, co je již dlouho významnou sférou zájmu v oborech mediálních studií (Reese 2003 aj.), ale i dalších oblastí vědění (zejm. sociologii, politické teorii nebo v psychologii, viz např. Tversky \& Kahneman 1981 aj.).
} 
pomoci zjistit, co dovoluje nějakému životu stát se viditelným v jeho nezajištěnosti a co nám brání v takovém nazření a chápání jiných životů.

Význam problematiky je zjevný, když si uvědomíme, že důmyslné „rámování“ jakékoliv události nebo problému může mít velmi silné důsledky pro posuzování situace osobami, které jsou účinkům organizujících principů, popisujících a charakterizujících určité objekty, vystaveni (slavně viz Kahneman \& Tversky 1984). Vytvoření, ba dokonce vnucení dominantní či jakékoliv jiné požadované perspektivy na objekt je potom snazší zvlášt' u př́ijemců bez vědomí nutnosti kritického čtení a myšlení, kteří ono sdělení obvykle zjednodušeně vnímají ve smyslu přínosů či ztrát, které by jim mohlo $\mathrm{v}$ předkládané podobě přinést. A právě rámování sdělení o události či problému ve smyslu přínosu (za účelem pozitivního přijetí publika) či ztráty (při potřebě negativní recepce tématu veřejností) je implicitně obsaženo ve škále využití tohoto nástroje, který tím skutečně získává potenciálně vysoký společenský vliv (zvlášt' při vědomí toho, jak fungují další spojité, ba synergické koncepty, např. bandwagon efekt - Lazarsfeld, Berelson \& Gaudet 1944 či spirála mlčení - Noelle-Neumann 1984 nebo vybrané kognitivní omyly-biasy, zejm. konfirmační zkreslení - Hasselton, Nettle \& Andrews 2005, příp. i některé varianty reakce na kognitivní disonanci - Festinger 1957). Přesto není nezbytné rámování jakkoliv démonizovat, poněvadž v tom nejobecnějším smyslu výběr a zdůraznění atributů $v$ široké mediální agendě - je nap̌r. v podobě subjektivního přibarvení $\mathrm{v}$ podstatě pochopitelnou realitou médií a jakkoliv nezamýšlená distorze popisovaného objektu vlastně nutně doprovází práci mediálních pracovníků (problémový rozměr tkví proto spíše v úmyslu a stupni neobjektivity - srov. druhá část pozn. pod čarou č. 5 - který může ve svém extrému dosahovat až k záměrným a vysoce manipulativním způsobům rámování, typickým pro propagandu, včetně válečné propagandy; pro některá její specifika viz McQuail 2009, s. 546-548 a pozn. pod čarou č. 17).

Abychom toto byli schopni odhalit, je podle Judith Butlerové nutné zaměřit se zejména na metodu prezentace utrpení a na to, jak způsob prezentace ovlivňuje naši schopnost reagovat; afekt totiž podle autorky (s. 50) nikdy nenáleží jen nám, je od prvopočátku sdílen odjinud a dává nám možnost vnímat svět určitým způsobem vpustit $\mathrm{k}$ sobě určité dimenze světa a jiným odolávat. ${ }^{15}$ Válka přitom udržuje své

\footnotetext{
${ }^{15}$ Když autorka konstatuje, že je nemožné, abychom reagovali na násilí páchané na různých populacích se stejným zděšením, nebot' naše lidskost je implicitně rozdělena mezi ty, pro které cítíme naléhavou a nevysvětlitelnou starost, a ty, jejichž životy a smrt se nás nedotýkají anebo se nám jako životy vůbec nejeví (str. 50), odvolává se na antropologa Talala Asada jako jednoho z mnoha citovaných autorů v knize (zejm. s. 42-44). Jeho teze zní, že pocit'ujeme více morální hrůzy nad ztrátou životů v určitých podmínkách: „,když například někdo zabíjí ve válce nebo je v ní zabit, a tato válka je vedená státem, který považujeme za legitimní, jeví se nám taková smrt jako nešt’astná a smutná, nikoli jako radikálně nespravedlivá. Pokud se násilí dopouští skupiny povstalců, které považujeme za nelegitimní, pak se náš afekt vždy mění“. Takto řečeno jde myslím o triviální a třeba z pohledu zastánců tzv. teorie spravedlivé války
} 
praktiky právě působením na smysly a jejich přetvářením v ten způsob, kterým vnímají svět selektivně, čímž umrtvuje afektivní reakce na určité vjemy, zatímco afektivní reakce na jiné vjemy posiluje. Autorka si v tomto kontextu všímá uplatňování jistých norem ve veřejném diskursu v USA, jež ve svém důsledku ustavují, kdo je a kdo není člověk s nárokem na lidská práva (nejde přitom ani tak o ,př̌edpoklady pro to, aby něco bylo viditelné“, ale o vymezení „sféry jevení se“, protože sama naše schopnost „rozlišit a pojmenovat „bytí“ subjektu je závislá na normách, které toto uznání umožňují“ - s. 10-11). Proto se podle autorky stát snaží působit na poli vnímání, a obecněji na poli „reprezentovatelnosti“, aby kontroloval afekt - „, očekávání způsobu, jakým je afekt nejen strukturován interpretací, ale jakým sám strukturuje interpretaci“ (s. 68-69).

K podmínění a strukturování našich afektivních reakcí jsou využívány opakovaně zmíněné interpretační rámy, které zprostředkovávají realitu ve vztahu k válce a o kterých autorka tvrdí, že jsou řízeny dominantními médii liberálního Západu (s. 16 a 136), jež za pomocí různých metod afektivně, vizuálně a diskursivně řídí kolektivní vnímání pojmu ,žitý život““ a určují, jak je alokována „rozpoznatelnost“ určitých „,figur lidskosti“ (s. 62). Někteří lidé tak své lidství mohou považovat za nezpochybnitelné, zatímco jíní za něj musí bojovat (s. 71). Autorka si všímá, že k tomu v případě válečných událostí přispívá i nařizování, co smí být viděno ${ }^{16}$ a celkově vizuální způsoby

(např. Moseley 2011 aj.) zcela neproblematické tvrzení (závažnější problém pochopitelně představuje hledání způsobů a mechanismů, které regulují naše rozumění tomu, čí skutky vidíme jako ospravedlnitelné - typicky se uvádí ekvivalentní činy, které svým charakterem jdou mimo rámec ius in bello (viz Orend 2008), jež jsou leckdy u moderních pravidelných armád považovány za legitimní, zatímco u militantů tomu tak je zřídka. Druhým vpravdě klíčovým problémem je potom pátrání po konkrétních normách jednání, které by bylo lze universálně za ospravedlnitelné považovat. To je koneckonců i předmětem polemiky Talala Asada s prominentním teoretikem spravedlivé války Michaelem Walzerem, jež je rekapitulována a okomentovaná autorkou na s. 130-140). Zcela závěrem ještě pokus o vyvození normativních důsledků, vyplývajících z vypozorovaného zjišstění, že prožíváme šok a rozhořčení při setkání s jedním projevem násilí, zatímco na jiný reagujeme s chladem, jak je předkládá Jean-Jacques Rousseau (1978, s. 170): „zdá se, že lidské cítění prchá a slábne, rozšiřuje-li se na celou zemi, že neštěstím v Tatarsku nebo $\mathrm{v}$ Japonsku nedovedeme být tak dojati jako neštěstím některého národa $\mathrm{v}$ Evropě. Je zapotřebí umět určitým způsobem omezit a potlačit zájem i soustrast, abychom je učinili činorodými. Naše náklonnost může přinést užitek pouze těm, s nimiž je nám dáno žít, a proto je v pořádku, že lidské cítění se soustřed'uje na spoluobčany, nebot' vzájemné styky a zájmy se nejen spojují, ale i posiluji“", srov. pozn. pod čarou č. 10).

${ }^{16}$ Sousloví „to, co smí být viděno“ nabízí zastavení u konceptu tzv. agenda setting neboli nastolování agendy (Dearing \& Rogers 1996 či McCombs 2009). Základní myšlenkou je, že zpravodajská média pomocí nastolování agendy vlastně naznačují veřejnosti, co považovat za hlavní otázky dneška (to lze ovlivnit samotným zařazením, ale i např́. řazením zpráv, signalizujícím jejich důležitost atp.), přičemž teorie tvrdí, že „nastolená témata“ se posléze doopravdy odráží v žebříčku vnímání nejdůležitějších aktuálních záležitostí u veřejnosti, aniž by byla v těsné shodě s ,tématy skutečného světa“. To, proč se některé problémy a události stanou součástí veřejné debaty a jiné nikoliv, tak vysvětluje teorie nastolování agendy právě schopností kontrolovat, co je předkládáno $\mathrm{k}$ diskusi v jakémkoliv systému, ve kterém identifikujeme vstupy a výstupy (viz např. Easton 1965, s. 70-149). Nejefektivnějším prostředkem k získání vlivu na 
účasti na válce (opakovaně tvrdí, že způsob, jakým reagujeme na utrpení druhých, závisí na daném, již ustaveném poli „,vnímatelné reality“ - s. 62). Jako konkrétní př́íklad uvádí situaci po zahájení tzv. druhé války v Iráku (2003), kdy státním orgánům ke kontrole a řízení informací, jež proudily $\mathrm{k}$ veřejnosti, posloužil institut tzv. „doprovázejících novinářư“ (v orig. „embedded reporting“, jinak též embedded journalism ${ }^{17}$ ), kteří participovali na určování toho, co bude, či nebude zahrnuto do pole vnímání.

makroúrovni celospolečenského veřejného diskursu je potom ovládnutí masmédií a faktický dozor nad tím, aby některá témata byla zařazena do jejich obsahů a jiná nikoliv, viz (McCombs \& Shaw 1972, příp. Trampota 2006, s. 112-122 či Kalvas 2009). Pomocí tohoto nástroje - který je velmi úzce spojen s kontrolou tzv. filtrů či uzlových bodů (tzv. „gatekeepers“, viz zejm. Lewin 1943, př́íp. Shoemaker \& Vos 1999) - lze teoreticky velmi efektivně strukturovat obsah diskursu a je-li vše propojeno s výše zmíněným rámováním, tak i pojetí kteréhokoliv problému. To se dá činit nejen prosazením témat, která vůbec budou připuštěna $\mathrm{k}$ reflexi („,o čem myslet“), ale i ovlivněním podoby, v jaké budou prezentována (,co si myslet"). Není pochyb, že právě o rafinované koordinaci všech těchto prostředků autorka mluví, když tvrdí, že „vedení války, jeho praxe a důsledky, mají být ustaveny perspektivou, kterou formuje a povoluje ministerstvo obrany, a tím ilustruje moc státu stvrzovat, co budou lidé přijímat jako realitu: určuje rozsah toho, co může být vnímáno jako skutečné“" (s. 64). Na druhou stranu média pochopitelně nejsou v tomto kontextu všemocná, na což upozorňuje např. McQuail (2009, s. 527-530), který odkazuje na přesvědčivé doklady, že lidé sice skutečně „přemýšlejí o tom, co jim je řečeno“, ale na žádné úrovni si bezvýhradně „nemyslí to, co jim je řečeno“.

17 Doprovázející novináři mohou být využiti jako součást snah o kontrolu informačního prostředí, která s rostoucí medializací konfliktů nabývá na důležitosti, nebot' veřejné mínění (na které působí) se stává stále významnějším faktorem pro legitimizaci vojenských akcí (Hoskins O’Loughlin 2010). A je to právě míra přesvědčení o legitimitě určitého jednání, jež dosud představuje jeden z fundamentálních předpokladů úspěšné mobilizace - skutečné i „psychické“ - obyvatelstva, která je i dnes pro úspěch v boji esenciální. O urputné snaze a extrémním úsilí všech zainteresovaných stran co nejpřesvědčivěji vykreslit válečné události specifickým způsobem (rozuměj: ve svůj prospěch) se občas hovoří jako o informačních nebo mediálních válkách (Hutchinson 2006 aj.), srov. virtuální války (Ignatieff 2001, ve vztahu k mediálním válkám zejm. s. 144-148; a zpátky k virtualitě války ještě např. Baudrillard 1995), kybernetické války (např. Ventre ed. 2011 aj.), psychologické války (klasicky viz Linebarger 1954 aj.) nebo i některé další vzájemně propletené pojmy z oblasti nekonvenčních způsobů boje příp. konceptu tzv. hybridní války (Murray \& Mansoor eds. 2012). Za přelom v intenzitě mediálního pokrytí válečných konfliktů bývá uváděna Vietnamská válka (1963-1975) nebo první irácká válka (též Válka v Zálivu, tj. 1990-1991), viz (Allan ed. 2004; Carruthers 2011). První zmíněný konflikt zosobňuje př́klad vládou př́liš neregulovaného a neomezovaného referování investigativních reportérů o událostech, prrípadně i referování zaměřené přímo proti konání vlády, tj. $\mathrm{v}$ tomto prŕípadě protiválečně zabarveného (napřs. Volek 2002, srov. Hallin 1989; Wyatt 1995; Hammond 1998 aj.). To lze výstižně shrnout výrokem tehdejšího prezidenta USA Richarda Nixona „naším největším neprrítelem se zdá být tisk" (dle Pach 2010, s. 555). Druhá jmenovaná představuje ukázkové „poučení“ vládních představitelů o nutnosti pečlivě kontrolovat mediální výstupy a vytvářet žurnalistům takové podmínky, ve kterých by mohli poskytovat veřejnosti „příznivé“ pohledy na události, viz napřr. newspool system aj. opatření (Taylor 1998). Již tehdy byli doprovázející novináři přidružení $\mathrm{k}$ vojenským jednotkám součástí taktiky působit určitým způsobem na veřejné mínění na „domácí frontě“ (srov. Sontagová 2011, s. 61, která uvádí jako vůbec první př́ípad Válku o Falklandy - 1982). A jelikož výsledkem byla (nepochybně i 
Tento nástroj umožnil armádním představitelům USA zásadní regulování obsahu pomocí dohledu nad perspektivou, ze které mohli novináři dění sledovat. Něco vidět $\mathrm{v}$ podstatě znamenalo zaujmout určitou pozici, vymezenou podle předem daných parametrů vojenskými autoritami a předpokládalo jistou dispozici samotného subjektu s možností sledovat pouze určité události a vojenské akce a informovat jen o určitých př́ibězích (zároveň lze předpokládat, že novináři pracující za těchto podmínek nebudou otázku samotného vynucení perspektivy tematizovat a činit z ní předmět diskuse, protože do války byli vpuštěni jen ti z nich, kteří dopředu přistoupili na podmínku, že jejich pohled bude vymezen podle stanovených parametrů). Je třeba dodat, že informace předkládané tímto způsobem nečekají na interpretaci svého př́ijemce, ale samy aktivně interpretují a to někdy i dost násilně (s. 62-63).

Vstupují-li poté takto rámované informace (v knize je konkrétních snah o ovlivnění popsáno vícero) do „diskursu humanizace“ s klíčovou otázkou: „který zničený život může být veřejně oplakáván a který zanechá jen částečnou, nečitelnou, nejasnou stopu nebo nezanechá stopu vůbec žádnou?“"(s. 70), vzniká podle autorky extrémní nebezpečí, že vnucený rám - vymezující, co je možné vnímat, ba a co dokonce „může být“" (s. 89) - povede publikum k neblahé diferenciaci mezi obět'mi. Ta se bude řídit logikou, ve které vybrané skupiny, s nimiž je snazší se skrze rámované informace identifikovat, budou oplakávány, zatímco jiné nikoliv. Restrikce ve vztahu k tomu, co můžeme slyšet, číst nebo vidět tímto způsobem podrývá objektivní uchopení války a v konečném důsledku i podmínky pro opozici vůči ní. Zde se autorka patřičně ptá, zdali omezováním toho, jaké zprávy a sdělení k nám proudí, „,vláda a média neomezují také to, jaké druhy důkazů má veřejnost $\mathrm{k}$ dispozici, aby mohla soudit, nakolik moudře je válka vedená a jaké je její směřování?“"(s. 75).

Nad výše zmíněnou otázkou se lze zamyslet za využití konkrétního prríkladu uvedeného v knize, kde se autorka extenzivně zabývá analýzou snímků z nechvalně proslulé věznice Abú Ghrajb v Iráku. Ty okamžitě po svém rožšřrení po světových komunikačních kanálech zapř́íčinily silný odpor vůči válce $\mathrm{v}$ Iráku a vyvolaly opodstatněné pochybnosti o její legitimitě. Někteří konzervativní televizní experti tehdy autocenzurně tvrdili, že ukázat je ve vysílání, by bylo „neamerické“ či přímo „protiamerické“ (s. 42-43). Později se proti zveřejnění jiných fotografií, dokumentujících přestupky amerických vojáků v Afghánistánu a Iráku, postavil s velmi podobnou argumentační logikou i americký prezident Barrack Obama (2009), když prohlásil, že by zveřejněni ,zažehlo antiamerické nálady a vystavilo naše jednotky

\footnotetext{
z jiných důvodů) ,všeobecná poslušnost tisku“ s monopolním přesunem informací i obrazového zpravodajství směrem k domácímu publiku - což se zároveň považuje za významný faktor, podílející se na úspěchu celé operace (Dorman 1997) - byli opakovaně a masivněji využiti i v druhé irácké válce (2003), viz např. (Miller ed. 2003; Lewis et al. 2006), o čemž přesně autorka hovoří.
} 
nebezpečí“. Dosavadní výsledky již více než 12 let trvajícího soudního sporu o zveřejnění dávají za pravdu spíše zastáncům transparentnosti z řad American Civil Liberties Union, nebot' na základě nedávných rozhodnutí soudních autorit bylo ministerstvem obrany USA několik stovek (z více než 2000 snímků) fotografií uvolněno (Ackerman 2016), přičemž o publikování dalších se bude dále jednat.

Snímky ostudného, ohavného a absolutně zavrženíhodného zacházení se zajatci a vězni (těžko říct, zdali to vše činí ještě více alarmujícím, ale podle odhadu, který zmiňuje zpráva Červeného kř̌̌že o zacházení s vězni v první fázi války v Iráku, bylo cca $80 \%$ uvězněných ,zatčeno nesprávně“ (Report of the Internatonal Committee of the Red Cross... 2004), brutálně pošlapávajícího Ženevské úmluvy (2005), ba samotné základy vzájemného jednání mezi lidmi, samy o sobě jistě neukazují zcela objektivní a vyvážený pohled na všechny aspekty intervence v Iráku. Jakkoliv však lze věřit (či doufat), že jsou prezentací toho zdaleka nejhoršího z nejhoršího, co se událo, už samotný fakt, že k zachyceným činům $\mathrm{v}$ důsledku intervence došlo, na ni vrhá velmi negativní stín jako na celek. I kdyby se jednalo o absolutně minoritní epizodu z hlediska celkového chování intervenčních vojsk v Iráku, šlo o reálnou součást toho, jak je válka vedena a jako součást všech dostupných důkazů to bylo správné vzít coby relevantní faktor do úvahy při jejím hodnocení.

I při plném vědomí toho, že fotografie pomohly vytvořit přehnaně negativní obraz USA a zapříčinily skokovou erozi důvěry (nejen) v zahraniční a bezpečností politiku USA, ale vyústily i ve mnoho dalších negativních konsekvencí pro tuto zemi, souhlasím $\mathrm{v}$ tomto ohledu s Judith Butlerovou, že americká veřejnost měla mít možnost dozvědět se o aktivitách armády v souladu s nejlepšími demokratickými tradicemi participace a deliberace (jestliže v důsledku uveřejnění byly od emocemi pohlcených lidí spáchány na základě principu kolektivní viny - skutky poškozující nevinné americké občany, nelze $\mathrm{z}$ toho podle mne obviňovat advokáty zveřejnění snímků). Poté, co již k mučení došlo a byly z něj pořízeny obrazové záznamy, otištění bylo myslím správnou reakcí, nebot' absence konkrétního důkazního materiálu by potlačila kontrolní mechanismus, který veřejnost $\mathrm{v}$ demokratickém politickém systému př̀edstavuje (i v tomto případě to dopomohlo ke spuštění některých autokorekčních mechanismů systému, zajištění potrestání viníků atp.). Představa, že se někde v minulosti děly (či v současnosti dějí!) podobné zvěrské činy, jejichž viníci zůstali vědomě kryti, čímžto se ani jejich skutky nedostaly na veřejnost, je velmi zneklidňující.

Samotné autorčině kritice aktů mučení tedy pochopitelně není co vytknout a i obhajoba zveřejnění se mi zdá být plně akceptovatelná, ovšem v představách a spekulacích o tom, co vše za těmito hrůznými činy stálo, se v knize zachází podle mého soudu občas příliš daleko. Konkrétně např. tehdy, když se podsouvá přímá souvislost nápisů „up your ass“ na hlavicích bomb, které „homofobní“ armáda USA, „ejakulovala“ na Iráčany, právě s faktem ponižování se sexuálním podtextem ve věznici 
Abú Ghraíb (s. 81-82). Taková kritika v mých očích obsahuje nadlimitní množství psychoanalytické spekulace a spirituality (mimochodem evokuje koncept tzv. ,politické pornografie“, viz Vodrážka 2007, s. 81-113, zejm. 93-98). V tomto ohledu je myslím autorka zbytečně zaujatá i vůči tehdejšímu prezidentovi Georgi W. Bushovi, který jí svým vyjádřením o ,nechutnosti“ toho, co zhlédl po senátním promítání, zavdal příčinu $\mathrm{k}$ podezření $\mathrm{z}$ moralistního odsudku a primárního zhnusení z aktů „sodomie“ místo pozastavením se nad meritem věci, tj. důsledky mučení samotného (fyzické týrání a psychologicky ponižující podmínky ve věznici) (s. 79-80).

Nicméně ne všechny části analýzy (zejm. s. 70-90), popisující zneužití specifické zranitelnosti na rovině sexuality u osob muslimské víry (či osob pocházejících z kulturní oblasti islámského světa) lze odmítnout tak snadno. I když stojím za tím, že šlo o jednání, které je špatné, at' se provádí komukoliv a at' se jej dopouští kdokoliv, snad ještě více děsivá by skutečně byla představa promyšlené institucionalizace aktů mučení ve snaze nejen zadržené ponížit a donutit $\mathrm{k}$ absolutní rezignaci za účelem přiznání domnělých trestných činů nebo získání vojensky využitelných informací, ale bylo-li by to mučení vědomě „ušité na míru“ právě muslimům. Takové, které by opravdu obsahovalo vše, o čem si mučitelé myslí, že osoby z této populace nejvíce zraní v návaznosti na určitá tabu islámu - veřejná nahota, masturbace, homosexualita aj. (s. 110-115). K takovému přesvědčení ale nakonec nedospívá ani autorka: ,je doufám zřejmé, že akty mučení nechápu ani jako úchylky v konání jednotlivců, ani jako plně vědomé strategické cíle Spojených státư“.

\subsection{Centrální kategorie nezajištěnosti života a performativita jako východisko}

Proti všem výše popsaným silám, které brání našemu setkání s nezajištěností života druhého a jež záměrně produkují rozdílné kategorie žitých a nežitých životů, je nutné bojovat za účelem zabránit našim smyslům, aby podléhaly způsobům jejich regulace. Podle Judith Butlerové totiž př́ḱkaz nenásilí vždy předpokládá, že existuje nějaké pole bytostí, vůči nimž by nenásilí bylo příhodným přístupem. Jelikož je toto pole vždy vymezené, může nenásilí dostát své výzvě, jen pokud rozlišuje mezi těmi, na nichž se nenásilí nemáme dopouštět, a těmi, kteří s tímto příkazem zkrátka „,nejsou pokryti“ a zdají se být předurčeni do role obětí.

„Aby byl příkaz nenásilí smysluplný, je nejprve třeba odmítnout předpoklad samotného tohoto rozlišení - schematizovaného a neteoretizovatelného nerovnostářství, jež působí ve smyslovém životě (ano, jde o rámování pozn. MR). Pokud se prŕíkaz nenásilí nemá stát bezvýznamným, musí se spojit s kritickou intervencí ohledně norem, jež rozlišují životy, které se počítají jako hodné žití a hodné truchlení a těmi, které nikoli““(s. 153). 
Tomu se autorka snaží napomoci zkoumáním „podmínky vnímavosti“ a nabídnutím takové ,interpretační matrice pro pochopení války“, která představí oponenturu a „zpochybní dominantní interpretace“ (s. 52). Stejně jako existují normativně ustavené rámy, definující uznatelný a žitý život i s jejich opakem, je možná i existence na totožném principu vybudovaných rámů, usilujících o zpochybnění rozlišení mezi ne/uznatelnými a ne/žitými životy. Produkce nových rámů jako součást rozsáhlejšího projektu alternativních médií je jistě důležitá, nicméně pokud bychom si vystačili pouze s ní, unikla by nám základní dimenze problému - tím je ,iterabilní struktura rámu“ (s. 18). Naučit se rozeznat rám, který nás oslepuje před tím, co nutně musíme podle autorky uzřít (zejm. vzájemnou závislost a společně sdílenou nezajištěnost života, vedoucí k přijetí nenásilí a odmítnutí relativizace životů), není snadný úkol. V pojetí Judith Butlerové tak nakonec „,nejde o to odhalit, co je „uvnitř‘“ nebo „vně“ rámu, ale co kolísá mezi těmito pozicemi a co se jakožto zavržené stává součástí (v orig. „encrypted“, s. 75 - pozn. MR) samotného rámu“ (s. 70). Přijetí takového konceptu nám umožní postavit se za hodnotu lidského života a reagovat $\mathrm{s}$ rozhořčením, když jsou životy pomocí rámování degradovány nebo je z nich vyjímána jejich podstata bez ohledu na jejich universální hodnotu (s. 72).

Hlavní přínos daného přístupu pochopitelně spočívá v možnosti tvrdit, že vše, co je eventuálně vyloučeno z rámů, je stejně tak důležité a cenné jako to, co je v nich obsaženo. I proto v zásadě platí, že na otázku, jejíž artikulace se nabízí (,co by to znamenalo, kdybychom veřejně truchlili přímo pro oběti našich vlastních válek?"“ a jejíž podstaty se autorka dotýká už v jiném svém starším díle (Butler 2002), kde demonstruje nutnost truchlit za všechny druhé, včetně nepřátel a těch, kteří stojí mimo rámy uznání většiny), lze odpovědět: význam toho tkví ve zdůrazňování křehkosti a nezajištěnosti života. Požadavek nenásilí potom vychází zejména z odmítnutí vlastní exkluzivity sebe jako „ego“"18 , a jeho nahrazením sebe jako bytosti „svázané s druhými neoddělitelným a

18 Ačkoliv autorka mluví opakovaně o „,egu“ (s. 45, 47, 148-149 či 153), nikterak exaktně nespecifikuje a nedefinuje jeho pojetí, ani se nepřihlašuje $\mathrm{k}$ žádné tradici zkoumání ega $\mathrm{v}$ rámci vědního oboru psychologie. Známý je samozřejmě rozbor ega u zakladatele psychoanalýzy Sigmunda Freuda (byt' i on sám vnímal obsah pojmu v průběhu času různě). Jestliže zpočátku bylo ego chápáno víceméně jako synonymní termín k pojmům typu osobnost, self nebo vědomí, ve slavném článku Ego a Id (1923, srov. Butler 1990, s. 57-65) se pojetí mění a ego se stává jednou ze součástí tripartitní struktury osobnosti ve složení Id, Ego a Superego (kde je zjednodušeně řečeno zodpovědné za racionální rozhodnutí a mediaci mezi oběma zbylými složkami). Později se Freud vyjadřoval o egu jako organizaci naplňující funkci obrany, testování reality, vnímání, atp., nicméně to už v oboru aktivně působila i Anna Freudová (zejm. 2006) nebo Heinz Hartmann (1958), kteří navazují na strukturální teorii a coby zakladatelé moderní ego-psychologie důkladněji rozebírají funkci ega ve smyslu adaptace k vnějšímu světu. Do takto vytyčené linie osobností psychoanalýzy svým profesním zaměřením zapadá i Melanie Klenová, která je navíc v knize namnoze citována. Nicméně svod dedukovat (či spíše spekulovat), že právě její význam pojmu ego používá i autorka, je částečně zapuzen autorčiným prohlášením: ,jak víme, Klein není žádná psychoanalytička ega“ (s. 47). Přesto - byt’ s pokorou a nikterak definitivně - předkládám koncept ega užívaný Judith Butlerovou, jak se jeví 
nezvratným způsobem“, bytosti „existující v zobecněné podmínce nezajištěnosti a vzájemné závislosti“ (s. 153). Tu si lze představit jako určitý komplex podmínek, nezbytných pro existenci každého individua, avšak s omezeným vlivem jednotlivce na jejich fungování, z čehož vyplývá, že právě ti druzí mají vždy naše životy v rukách. Vědomí vlastní nezajištěnosti u všech subjektů, tj. že ani my, obyvatelé „,prvního světa“, nejsme v bezpečí, jak se někdy samo sebou rozumí (jsme jen aktuálně ekonomicky a vojensky silnější, avšak principiálně shodně nezajištění), je mimořádně důležitým předpokladem úspěšného odvolávání se na nenásilí. ${ }^{19}$

Politicky motivovanou knihu Judith Butlerové je v tomto kontextu možné považovat za kritiku těch pojetí politického subjektu, jež předpokládají, že zranitelnost může být monopolizována na jednom místě a zcela odmítnuta na druhém, nebot' „žádný subjekt nemá monopol, aby „byl perzekvován“ nebo „perzekvoval“, naopak se hovoří o všeobecné „rovnosti v nezajištěnosti“ a „nutném boji za zachování vnímavosti vůči proměnlivé povaze rovnosti - a nároku druhého na přístř̌eší - což je neuvěřitelně těžké hájit“ (s. 154, resp. 153 a 156). A v tom leží i odpověd’ na další z výše formulovaných otázek (,jaká je naše odpovědnost vưči těm, kteří skončí vně rámů a vưči těm, které neznáme a kteří jsou daleko od nás?“), dobře čitelná z diskusí o vzájemném vztahu mezi

v kontextu sdělení knihy: totalita psychiky a somatiky ve vztahu $k$ subjektu a jeho identitě, spojená s vnímáním sebe sama coby individuálního, samostatného aktéra, odděleného od jednoty s ostatními, srov. s vybranými dalšími návrhy na uchopení vlastního já coby českého ekvivalentu z latinského ego (originálně v primárních zdrojích viz např. Blackmoreová 2000, s. 253-282, přehledově v sekundárním pojetí viz např. Mikšík 2007 a ve vztahu k tématu i kapitola Agrese, osobnost a vztah k vlastnímu já viz Čermák 2003, s. 23-56). Autorka tedy jde proti Kleinové (s. 45-47, viz též zdejší pozn. pod čarou č. 12), když kritizuje i egocentrismus (srov. idiocentrismus viz Triandis 2000, s. 118-119) ve smyslu: chápání a hodnocení jevů ve vztahu $k$ sobě a $k$ významu, které mají pro vlastní já, ale hlavně egoismus: jednání, které je zcela zaměreno na prospěch vlastní osoby; lze říct i sobectví jako protiklad k altruismu (eo ipso platí, že egoismus je vždy egocentrický, egocentrismus však neznamená egoismus, viz Geist 2000, s. 48, srov. 105-106). Judith Butlerové by tak teoreticky mohlo být blízké allocentrické já (Triandis 2000, s. 118-119), které tvoří osobnost více nezištně orientovanou na podporu a pomoc druhým, zde navíc bez ohraničení úzkou členskou skupinou. A je-li hodnocená kniha o truchlení a oplakávání, zcela závěrem lze ještě zmínit, že v práci se signifikantním názvem Trauer und Melancholie (tj. Truchlení a melancholie; česky ovšem vyšlo jako Smutek a melancholie - 2002, s. 363-378) Freud popisuje, ego př́značně jako ,schránku opuštěných objektů“. K tomu více viz Blanck \& Blanck 1992, s. 20 nebo Jacobson 1964.

${ }^{19}$ Je zajímavé konfrontovat přesvědčení Judit Butlerové o tom, že všeobecná nezajištěnost a vědomí vlastní zranitelnosti povedou $\mathrm{k}$ přijetí nenásilí, se závěry dalších autorů, kteří např̀. v konceptu známém jako bezpečnostní dilema (klasicky viz Herz 1950, 1951) představují a vysvětlují zcela jiné scénáře chování aktérů, jež si uvědomí vlastní zranitelnost, způsobenou nedostatečným zabezpečením ve vztahu k aktérům ostatním, viz např. (Drulák 2003, s. 62 či Waisová 2009, s. 110-111). To je ovšem způsobeno zejména paradigmaticky odlišným světonázorem mezi Judith Butlerovou a politickými realisty, viz např. (Kratochvíl \& Drulák eds. 2009, s. 35). Lze si vlastně docela dobře představit výklad pojmu bezpečnostní dilema, který nijak nefalsifikuje teze autorky, nýbrž je naopak podporuje (viz např. Drulák 2003, s. 189) aj. 
subjekty. V nich autorka hájí pozici, kde základním referenčním bodem není jednotlivec, ale struktura a sít' mezilidských vztahů. Ostatně opakovaně bylo řečeno, že až všichni druzí jsou pro nás samé určující neboli „,všechno to, čím se lidské bytosti stávají, se konstituuje jako průsečík mezilidských vztahů a společenských institucí, na nichž jsou fundamentálně závislé“ - Butler 2013b). Vznik žádného subjektu není možný bez pozitivního či negativního pouta s druhými, tj. ani bez závislosti na nich: at' už jde o závislost na lidech nám známých, sotva známých anebo zcela neznámých. To, čemu říkáme agrese, se může pohybovat směrem $\mathrm{k}$ anihilování druhého, ale pokud to, kým jsme, je právě sdílená nezajištěnost, pak riskujeme vlastní anihilaci (s. 155).

Představené chápání nezajištěnosti života a z ní vyplývající zranitelnosti je třeba považovat za klíčové aspekty determinující politickou činnost. Její součástí musí být podkopání té funkce rámů, která stojí za determinací, co bude a co nebude životem hodným truchlení. Zpochybnění rámů, jež podle Judith Butlerové opakovaně umožňují válce existovat, je nezbytným předpokladem $\mathrm{k}$ tomu, abychom vytvořili co nejvíce rovnostářskou množinu podmínek přiznání uznatelnosti a posunuli ji ve směru radikálněji demokratických výsledků (s. 13), tj. uspořádali politický život tak, aby bylo možné dosáhnout rovného uznání a reprezentace (s. 120). Takové jsou principiální cíle textu a asi nejzásadnější normativní otázky, které si autorka pokládá. Podle ní se nelze dobrat odpovědi, pokud neuvažujeme o nové ontologii subjektu a další úrovni, v níž operuje normativita, a to konkrétně skrze normy, které produkují ideu člověka, jenž je vůbec hoden zmíněného uznání a reprezentace. V kontextu všeho vyřčeného pak není překvapivé, že za fundamentální se v tomto ohledu znovu považuje pochopení rozlišující moci, která zde působí a která diferencuje mezi subjekty, jež se o uznání vůbec mohou ucházet, a těmi, které nemohou.

Na závěr prezentace obsahu knihy Judith Butlerové je důležité upřesnit, že ona sama od úplného počátku své akademické činnosti konstatuje neexistenci jakési odosobněné apriorně jednající Moci či Řádu s velkým počátečním písmenem, když místo toho popisuje pouze „existenci opakovaného jednání, které je mocí v její setrvalosti a nestálosti“ (1993, s. 9). A v tom tkví nerevoluční potenciál změny, poněvadž pro efektivní uskutečňování její reformy stačí využít mechanismu iterace opakovaného jednání, jenž po vnesení dostatečného množství nových prvků, jdoucích proti převládající normě, sám zajistí její postupnou destabilizaci (srov. Derrida 1993, s. 277-306). Kvůli tomu, že za vznikem „mocenského řádu“ nestojí žádný zásah uskutečněný institucionálně zvenčí, ale naopak je zrod procesuální záležitostí, není ani za účelem změny možné rozložit jej zvenčí; děje se tak pouze skrze jednání uvnitř. V souladu se svými postuláty z předchozích publikací Judith Butlerová proklamuje i zde, že cestou ke zpochybnění rámů je vnitrosystémové opakování všemožných subverzivních aktů, jež v důsledku vytvoří další prostor pro lépe zajištěnou existenci skutečně všem rozmanitým populacím bez výjimek. Př́istup k procesu ovlivňování výsledných norem je absolutně klíčový, a proto být plnohodnotným občanem 
neznamená jen být uznán, ale hlavně získat klíčové právo účastnit se debaty o podmínkách uznání (s. 121).

K tomu je vhodné znovu upozornit, že popisované řešení obsahuje rysy, jež jsou společné pro celý korpus díla Judith Butlerové a nesou s sebou způsob, jimž lze „cestovat časem“ autorčinými pracemi až k prvním veřejnosti předloženým rukopisům. Ona přece i ta domněle statická rodová identita člověka, vystavěná na příslušnosti k jednomu ze dvou přirozeně daných pohlaví, nestojí na počátku coby jakási vlastní sebe-podstata, podmiňující chod věcí, ale vyjevuje se až na konci dění jako konstrukt a „výsledek působení institucí, praktik a diskursů, jejichž počátky jsou pluralitní a rozptýlené (1990, s. XI), srov. s textem známého hitu „(You Make Me Feel Like) a Natural Woman“ (Franklin 1967) neboli podle autorky přirozenost není dána přirozeností, ale spíše tím, co si pod přirozeností představujeme.

A zrovna tak jako $\mathrm{v}$ hodnocené knize, i v prvních publikacích autorky se diskutovalo o odkrytí mechanismů, jimiž jsou konstruované sociálně-kulturní regulační normy režimu moci a diskursu, přičemž motivací $\mathrm{k}$ jejich pochopení bylo zejména osvojení schopnosti efektivně je zpochybňovat a podrývat. Pro tento cíl, jak apeluje autorka rovněž v Rámcích války, by se měly propojit a solidárně sjednotit všechny menšiny (což se již děje, konkrétní příklady viz s. 126-127) bez přístupu k prosazení vlastního vlivu na regulační normy, jež je ve své současné podobě ohrožují. Explicitní uvádění souvislostí mezi hodnocenou knihou a ranými pracemi má vést mj. i $\mathrm{k}$ pochopení toho, že bez hluboké odbornosti získané dříve $\mathrm{v}$ disciplínách jako je feminismus nebo queer teorie, by mohla být jen těžko natolik kompetentně demonstrována snaha o zneužití tzv. „sexuální politiky“ za účelem démonizovat muslimy a vykreslit je jako nemoderní, zpátečnické a barbarské, která je součástí textu (viz zejm. s. 94-102 či 111-116). Mimochodem dnes to ve velmi podobné formě zaznívá i v diskusích o malé progresivitě, ba zaostalosti při posuzování např. homosexuality od imigrantů hlásících se k islámu.

\section{Shrnutí}

Hlavním zájmem Judith Butlerové jako akademičky je odkrytí mechanismů, jejichž výsledkem je násilí na diskriminovaných skupinách, a tak nepřekvapí, že i v hodnocené knize zkoumá, jakým zpo̊sobem se konstruuje různá hodnota životům, které prritom disponují shodnou nezajištěností a zranitelností. Problematizuje zde mnoho společenských procesů, opatření a politických rozhodnutí v tzv. „prvním světě“20,

\footnotetext{
${ }^{20}$ Termín, který autorka používá (např. 47, 73, 84, 89 aj.) bez dalšího vysvětlení (na rozdíl od mnohých jiných detailně zkoumaných) a to zjevně v intuitivním a obecně chápaném smyslu, označujícím po konci bipolárního rozdělení cosi jako - prosím bez ambice na dokonalou a vyčerpávající charakteristiku - industrializované, ekonomicky a materiálně rozvinuté země (měřeno napřr. HDP) s demokratickým systémem vlády a kapitalistickým řízením hospodářství.
} 
nicméně sympatické je, že podrobuje kritické zkoušce i své vlastní teze. Přichází s jasnými etickými závěry a bez náznaku alibismu se zřetelně přihlašuje $\mathrm{k}$ jednoznačné názorové pozici v podobě maximální možné podpory marginalizovanému subjektu a velmi heterogenního a denacionalizovaného pojetí lidu s holistickým přístupem k pojmu my. Aktivně vystupuje proti tendencím agresivního rasismu, nacionalismu, sexismu, misogynie a homofobie a dalším formám diskriminace (o nichž tvrdí, že jsou obsaženy do násilné mediální taktiky rámování). Stejně tak nekompromisně kritizuje neoliberální procesy a politiky spolu se všemi (zejm. pravicovými) antidemokratickými podobami populismu potenciálně ohrožujícími lidská práva a svobody. Sama se mezitím veřejně přihlašuje k programu tzv. Nové levice, která podle ní stojí na piliřích solidarity, odporu proti různým zájmovým skupinám a závazku zlepšování demokracie (jakkoliv i směrem k tomuto proudu dokáže být v mnoha ohledech kritická - Butlerová 2016).

Pro plné porozumění textu Judith Butlerové je nezbytná předchozí iniciace do způsobu jejího myšlení a základní orientace ve specifickém diskursu (o což jsem se pokusil i zde $\mathrm{v}$ úvodu kritické statě představením základních ideových východisek a trvalých oblastí zájmu autorky). Knihu je nepochybně třeba chápat $\mathrm{v}$ rámci širšího kontextu předchozích děl a kontinuálního vývoje myšlení autorky. Judith Butlerové nelze upř́ít erudici, schopnost produkovat sofistikované myšlenky a podkládat je propracovanou argumentací, utvářející celý svébytný myšlenkový systém (přes značné množství inspirací u rozmanitých myslitelů nejde o pouhou eklektickou směsici), ovšem to vše je $\mathrm{v}$ daném případě vykoupeno jistou nepřístupností a čtenářskou nepoddajností textu. Ačkoliv v porovnání s předchozími knihami lze přece jenom pozorovat posun $\mathrm{k}$ poněkud čtivějšímu a jasnějšímu stylu, stále platí, že způsob, kterým autorka píše, je obecně obtížně srozumitelný (jakkoliv je zase tato skutečnost vyvážena pestrostí a rozmanitostí). ${ }^{21}$

Dnes by šlo v podstatě synonymně říct i „státy severu“, jakkoliv tam samozřejmě patř́ i Austrálie aj., které, vzato striktně geograficky, tomuto označení nekonvenují.

${ }^{21}$ To samozřejmě může mít minimálně dvě příčiny: některými je vysoce abstraktní uvažování považováno za do sebe zahleděnou akademickou pózu, snažící se ze superiorní intelektuální pozice zahalit vlastní texty do neprostupné aury důležitosti (např. Dutton 1998 či Nussbaum 1999), jindy se zdá být příčinou komplexita a složitost vyjadřované myšlenky, která neumožňuje použít triviálních prostředků sdělení (tak zní i obrana autorky, viz Butler 1999). K prvnímu se zejména $\mathrm{v}$ anglosaském světě občas v nadsázce - a někdy i bez nadsázky - říká: ,je to prríliš nejasné, aby to bylo nesprávné“, ale chceme-li vážně přemýšlet, jestli do této kategorie autorka nespadá, možná pomůže výstižné konstatování pisatelky doslovu hodnocené knihy L'ubici Kobové. Ta poznamenává, že jasnost argumentů a rigoróznost v tom smyslu, jak ji pěstuje a vyžaduje např. tradice analytické filozofie, je pro autorku neatraktivní, když namítá, že: „ked' sa štandardy jasnosti stanú súčast’ou hermeticky uzavretej disciplíny, prestávajú být’ komunikovatel'né, a vo výsledku tak paradoxne dospejeme k nekomunikovatel'nej jasnosti“ (s. 162). Ostatně to také vysvětluje, proč se při zkoumání podmíněnosti poznání neinspiruje Richardem Rortym (1991; 2012) nebo W. V. O. Quinem (1992; 1995) aj., ale spíše Michelem Foucaltem (2002) či Jacquesem Derridou (1978). Při hodnocení stylistiky autorky lze ještě 
Jde sice o téma, které se dotýká širokých mas populace, nicméně relativně nepoddajný text, plný těžkopádných a dlouhých souvětí (navíc dále obohacených o řadu terminologických neologismů), dává již od první kapitoly na srozuměnou, že byl napsán jen pro relativně úzké publikum (méně odhodlaného čtenáře je patrně vhodné odkázat na př́istupnější interpretace, které převádí obsah knihy do „běžného jazyka“") ${ }^{22}$. Požadavek opravdu zvýšené pozornosti, soustředěnosti a trpělivosti částečně neguje „mobilisační potenciál“ a neumožňuje vyvolat širší společenský dopad, pro který by byla nezbytná jednodušší možnost identifikace s předkládanými argumenty. $\mathrm{V}$ tomto ohledu vyvstává otázka, zdali zvolená komplikovaná stylistika a velmi obtížně přístupné lexikum s mnoha ryze technicistními zastávkami pro exaktní definici pojmů neodsoudí realizaci principiálního cíle a poslání knihy - urgentní volání po více inkluzivním a radikálním politickém konceptu odporu k utlačovatelským mechanismům - k nezdaru.

Faktem je, že právě „úzkost vyvolávající nejasnost projevu“ (Dutton 1998) a vysoce abstraktní myšlení, vzdálené reálným problémům, někteří považují za pouhý projev elitářství. Subverzivní činnost, o kterou se autorka pokouší, na tomto základě označují za intelektuální stylizaci, zábavu a cíl sám o sobě, bez zamýšleného účelu dospět k ,lepšímu a spravedlivějšímu světu“. Jak dodávají, společenská kritika a v obecném smyslu řečeno ,analýza systému“ se míjí s jakýmikoliv praktickými dopady:

s nádechem humoru dodat, že k výčtu různých ocenění za excelentní intelektuální performance, zmíněných v úvodu tohoto textu, patř́i i cena časopisu Philosophy and Literature „Bad Writing Contest", ironicky vyzdvihující největší prohřešky akademiků proti literárnímu stylu a sarkasticky citující nejvíce obskurní pasáže (námitka, že je poněkud neférové vytrhávat několik řádků z kontextu, se samožrejmě nabízí). V prrípadě Judith Butlerové (1997a) šlo o úryvek z článku Further Reflections on Conversations of Our Time. V odpovědi na ,udělení ceny“ a další kritiku tímto směrem autorka reaguje již výše nastíněným způsobem, když se mj. hají tím, že „komplikovaný a nekonvenční jazyk je někdy potřeba za účelem sdělit myšlenku ve všech nuancích“ a spolu s využitím alternativního slovníku pomůže dostat se za obzor tzv. „zdravého rozumu, hájícího status quo“. $\mathrm{K}$ tomu předkládá i další důvody pro invalidaci obsahu její kritiky, viz (Butler 1999 aj.; další diskuse, jež to rozpoutalo, viz Smith 1999 a s odstupem času Birkenstein 2010).

${ }^{22}$ Nebylo cílem této kritické stati soustředit se detailně na editorskou a překladatelskou péči, která byla knize věnována, v zásadě však lze konstatovat, že překladatel si se složitým textem poradil dobře a rozhodně svým výkonem nikterak neztrpčil přístup $\mathrm{k}$ autorčiným myšlenkám. Samozřejmě není možné rozvést polemiku nad některými aspekty překladu a editorských zásahů na formátu poznámky pod čarou, přesto přikládám stručné ,errata“ a body do diskuse: např. Charles Tailor místo Charles Taylor - s. 12, našim místo naším - s. 77, potencionální potenciální - s. 75, jenž místo jež - s. 73, v pravdě místo vpravdě aj. či nedůsledný přístup k přechylování jmen, kdy se jednou mluví o „Sontagové“ a jindy o „Sontag“ (s. 66-67) nebo „Lynndie Englandová - Lynndie England“ (s. 75, resp. 166) a řada dalších. Podobně dopadla např. i Melanie Kleinová, o které se až na jednu výjimku (s. 148) důsledně mluví jako o „Klein“ bez přechýlení a skloňování, viz ,způsob, jakým tu Klein cituji ... má-li Klein pravdu ... pro Klein otázka přežití ... pokud přijmeme názor Klein, že ...“ (s. 46-47); přechylování poté neaplikuje ani doslov ke knize, ten je však alespoň při zacházení se jmény koherentní a drží se striktně jednoho jazykového způsobu práce s př́íjmením (srov. slovo překladatelky, viz NaglDocekal 2007, s. 306, že „nepřechylovat, neznamená neskloňovat“). 
prostřednictvím akademické činnosti Judith Butlerové „hlad žen nebude utišen, týrané ženy nenaleznou ochranu, znásilněné nenajdou spravedlnost a gayové a lesby nedosáhnout právní ochrany“ (Nussbaum 1999, s. 45). Třebaže lze rozumět linii této kritiky a je možné ji považovat v určitém smyslu za konstruktivní a adresující relevantní slabiny v úsilí autorky, domnívám se zároveň, že důkladná a hluboká analýza, která by vedla $\mathrm{k}$ pochopení př́íčin určitých jevů a mechanismů, které zase determinují jiné sociální procesy, může předcházet přijímání konkrétních praktických opatření, které nakonec mohou mít zcela konkrétní praktické společenské dopady. Ba naopak ukáže-li se, že analýza fakticky vyložila realitu takovou, jaká je - což potažmo přispělo k řešení problémů $v$ rámci společnosti - musí být hodnocena jako opodstatněná a vysoce žádoucí. Osobně vidím místo jak pro ryze teoretické a akademické pojednání o problému, tak i pro praktickou činnost, př́íp. aktivismus, jež se mohou vhodně doplňovat.

Po opublikování v anglickém jazyce byla kniha mnohačetně recenzována a dostalo se jí převážně pozitivního přijetí, viz (McGrath 2009; McRobbie 2009; Poole 2009; Rowe 2010; Watkins 2010; Withers 2010 aj.), což platí i o reflexi české verze (Fulka 2013a; Ptáčníková 2015). Domnívám se, že absence zásadní polemiky o knize samé vychází z četnosti již dříve formulované kritiky základních postulátů Judith Butlerové (na nichž stojí i tato kniha). Zjednodušeně řečeno možná převládl pocit, že není nutné provádět další repetitivní kritické kolečko. Ze stejného důvodu lze tvrdit, že ti, kteří autorku adorovali dosud, budou dílo považovat za brilantní analýzu obecných podmínek lidské existence ${ }^{23}$, obhajobu nenásilí, zachycení způsobu mediální reflexe války po 11. září 2001 a za bystrý a zasvěcený popis metod konstruování různě hodnotných životů - včetně poskytnutí návrhu možného boje proti tomuto procesu vytvářející kontury pro nové pojetí globální etické odpovědnosti a povinnosti nás všech ji respektovat. Nicméně ten, kdo nesouhlasí s fundamentálními tezemi Judith Butlerové ohledně konstruování genderu a úlohou, jakou v tom hraje performativita, nebude pravděpodobně spokojen ani s výslednou podobou zde hodnocené knihy.

Jelikož se forma a ideová východiska, na kterých kniha stojí, do podstatné míry podobají starším publikacím, je to zejména téma (válka a reflexe role médií ve vojenských konfliktech), které představuje novum v rámci celého díla Judith Butlerové. Na úplný závěr shrnutí a jako definitivní tečku za hodnocením textu se proto lze zastavit právě u autorčina značně kritického hodnocení médií. Jejich nepopiratelný význam při sociální konstrukci reality a jejich schopnost být klíčovým kognitivním systémem, selektujícím a distribuujícím obsahy, $\mathrm{k}$ nimž veřejnost obrací pozornost a jimiž je

\footnotetext{
${ }^{23}$ Mimochodem, jak je snad patrné z celé kritické studie, těmi podmínkami je cosi negativního zejm. nezajištěnost se svojí zranitelností, smrtelností atp. Proto je zajímavé srovnání se základními podmínkami, za nichž je člověku dán život na zemi, tak, jak je identifikovala ve svém díle Vita activa filozofka Hannah Arendtová (2007).
} 
formováno myšlení př́ijemců, pochopitelně činí z problematiky námět ke kritice par excellence (některé aspekty podrobně diskutovány i zde v pozn. pod čarou č. 14 a 16, příp. i na mnohých dalších místech recenze i jinde - za všechny ještě napřs. Luhmann 2014).

Pokud velkou část masmédií autorka kritizuje za to, že rozmanitými způsoby a strategiemi (tam patří rámování v obecném smyslu a konkrétně i např̀. inscenované obrazy kamer a fotoaparátů, zavádějící střih, autocenzura, zákulisní dohody $\mathrm{s}$ armádními představiteli atp.) napomáhají legitimizaci dělení životů na truchlení hodné a nehodné a volá po jejich reorganizaci (s. 16, 41, 51, 62, 75, 154), asi je pro úplnost vhodné dodat, že média nedokážou - a zřejmě ani při nejlepší vůli nemohou - v krátkých reportážních vstupech na ,jedné normostraně“ textu postihnout veškeré složité souvislosti dění válečných konfliktů. Domnívám se, že v tom ani nespočívá jejich primární úloha a kritizovat je za to by nebylo úplně opodstatněné. Pro hlubší analýzy jsou zde jiné platformy nežli denní zpravodajství, jakkoliv je třeba trvat na tom, aby právě na faktech z těchto zdrojů média své reportáže stavěla.

Nicméně ve válečných konfliktech - jako na maximum vyhrocených sociální situací dvou či více aktérů - se proponenti každé ze stran často snaží předkládat pouze ty informace, které potvrzují ,,jejich“ stanovisko, což nezávislým žurnalistům (a potažmo i divákům) orientaci v problematice přirozeně ztěžuje. Do této skupiny podle Judith Butlerové bohužel začasto patři i mnozí akademici a další výzkumné instituce, kde je již samozřejmě takové obvinění alarmující, nebot' kde jinde by měl člověk hledat protiklad vyprázdněnosti, zkratkovitosti a bagatelizace problému, nežli na univerzitách a výzkumných pracovištích, které jsou povinny sloužit jako zřídlo nezávislé kritické reflexe, podložené poctivým a důkladným vědeckým bádáním.

Je jistě pravda, že média by se ze své podstaty nikdy neměla dostat do služby politických a jiných zájmových skupin, nýbrž by měla ctít logiku svobodných sdělovacích prostředků, spočívající ve službě zájmům veřejnosti, mezi něž patří zpravodajství objektivní a pravdivé (tj. usilující v maximální možné míře o shodu popisu s realitou; sama autorka by asi s takovým tvrzením měla problém, a trvala by na tom, že také to, co bychom snad mohli považovat za předdiskursivní, lze vnímat pouze skrzeva určité diskursy, nebot' jedině prostřednictvím diskursů lze srozumitelně vyjádřit, co si pod jakýmkoliv vykládaným pojmem představujeme - čímž však toto předdiskursivní infikujeme určitými diskursy, eo ipso proměňujeme jej v diskursivní). Vzhledem k tomu, že dopad médií na veřejné mínění má značný potenciál, je od Judith Butlerové nepochybně správné upozorňovat na př́klady jejich selhání, aby si jednotlivec, na kterého tato média cílí, dokázal hrozbu uvědomit a veškeré důsledky působení rámovaní a dalších mediálních postupů byl schopen rozpoznat a adekvátně s nimi pracovat. To ovšem nevyžaduje nic moc jiného nežli pokusit se - srozumitelnou a přístupnou formou! - přivést nevědomé $\mathrm{k}$ vědomí. Jaká by totiž byla moc jakkoliv 
zprofanovaných médií ve společnosti složené výhradně z racionálně uvažujících jednotlivců, kteří fakta nepřijímají slepě, nýbrž uvážlivě hodnotí a ověřují je z více na sobě nezávislých zdrojů, čímž se k mediálním trikům, které Judith Butlerová kritizuje, stávají do značné míry imunní.

\section{Literatura}

Ackerman, S. (2016): „Nearly 200 Images Released by US Military Depict Bush-era Detainee Abuse.“ The Guardian (5. února). [online] dostupné z: <http://www.theguardian.com/us-news/2016/feb/05/us-military-bush-eradetainee-abuse-photos-released-pentagon-iraq-afghanistan-guantanamo-bay> .

Adorno, T. (2009): Minima moralia: reflexe z porušeného života. Academia, Praha.

Adorno, T. \& Horkheimer, M. (2010): Dialektika osvícenství. Oikoymenh, Praha.

Agamben, G. (2011): Homo sacer: suverénní moc a pouhý život. Oikoymenh, Praha.

Alford, F. (2001): „Levinas and Violence.“ Journal of Power and Ethics: An Interdisciplinary Review 2 (3): 243-258.

Allan, S., ed. (2010): Reporting War: Journalism in Wartime. Routledge, New York, NY.

Altez, F. (2007): „Banal and Implied Forms of Violence in Levinas’ Phenomenological Ethics.“ Kritike 1 (1 June): 52-70. [online] dostupné z: <http://www.kritike.org/journal/issue_1/altez_june2007.pdf>.

Atterton, P. (2009): „Levinas, Justice, and Just War.“ In Levinas In Jerusalem: Phenomenology, Ethics, Politics, Aesthetics - Amsterdam Studies in Jewish Philosophy, ed. J. Hansel 14: 141-153. [online] dostupné z: <http://ghansel.free.fr/atterton.html> (pod názvem „In Defense of Violence: Levinas and the Problem of Justice").

Arendtová, H. (2007): Vita activa. Oikoymenh, Praha.

Aristoteles (2009): Politika. Petr Rezek, Praha.

Austin, J. L. (2000): Jak udělat něco se slovy. Filosofia, Praha.

Balibar, É. (2015): Violence and Civility: On the Limits of Political Philosophy. Columbia University Press, New York, NY.

Barša, P. (1999): „Judith Butlerová: teorie performativního rodu a dilemata současného feminismu.“ Filosofický časopis 47 (5): 772-785.

Barša, P. (2002): Panství člověka a touha ženy: feminismus mezi psychoanalýzou a poststrukturalismem. SLON, Praha.

Bateson, G. (1972): Steps to an Ecology of Mind: Collected Essays in Anthropology, Psychiatry, Evolution, and Epistemology. Ballantine, New York. 
Baudrillard, J. (1995): The Gulf War Did Not Take Place. Indiana University Press, Bloomington.

Beauvoirová, S. de (1966): Druhé pohlaví. Orbis, Praha.

Benedictová, R. (1999): Kulturní vzorce. Argo, Praha.

Beste, J. (2006): „The Limits of Poststructuralism for Feminist Theology.“ Journal of Feminist Studies in Religion 22 (1): 5-19.

Birkenstein, C. (2010): „We Got the Wrong Gal: Rethinking the „Bad“ Academic Writing of Judith Butler.“ College English 72 (3 January): 269-283.

Blackmoreová, S. (2000): Teorie memů: kultura a její evoluce. Portál, Praha.

Blanck, G. \& Blanck, R. (1992): Ego-psychologie: teorie a praxe. Psychoanalytické nakladatelství, Praha.

Boucher, G. (2006): „The Politics of Performativity: A Critique of Judith Butler.“ Parrhesia, Issue 1: 112-141. [online] dostupné z: <http://www.parrhesiajournal.org/parrhesia01/parrhesia01_boucher.pdf>.

Butler, J. (1986): „Sex and Gender in Simone de Beauvoir's Second Sex.“ Yale French Studies, č. 72: 35-49.

Butler, J. (1990): Gender Trouble: Feminism and the Subversion of Identity. Routledge, New York, NY.

Butler, J. (1993): Bodies that Matter: On the Discursive Limits of Sex. Routledge, New York, NY.

Butler, J. (1997): The Psychic Life of Power: Theories in Subjection. Stanford University Press, Stanford, CA.

Butler, J. (1997a): „Further Reflections on Conversations of Our Time.“ Diacritics 27 (1): 13-15.

Butler, J. (1999): „A 'Bad Writer' Bites Back.“ The New York Times, 20. března. [online] dostupné z: <http://query.nytimes.com/gst/fullpage.html?res=950CE5D61531F933A15750C0 A96F958260>.

Butler, J. (2004): Precarious Life: The Powers of Mourning and Violence. Verso, London / New York, NY.

Butler, J. (2005): Giving an Account of Oneself. Fordham University Press, New York, NY.

Butler, J. (2002): Antigone's Claim: Kinship Between Life and Death. Columbia University Press, New York, NY.

Butler, J. (2007): „Gender Trouble: Still Revolutionary or Obsolete? - Interview with Judith Butler.“ In: Bang Bang. [online] dostupné z: 
<http://www.sophia.be/app/webroot/files/2006-2007\%20-

$\%$ 20Interview\%20with\%20Judith\%20Butler.pdf>.

Butler, J. \& Spivak, G. (2007): Who Sings the Nation State? Seagull Books, London, New York, NY.

Butlerová, J. (1999): „Kritické teploušství،“ Filosofický časopis 47 (5): 753-771.

Butlerová, J. (2008): „Podmanění, odpor, přeznačení. Mezi Freudem a Foucaultem.“ Česká literatura: časopis pro literární vědu 56 (6): 830-845.

Butlerová, J. (2013): „Svědomí z nás všech činí subjekty.“ Filosofický časopis 61 (2): 237-256.

Butlerová, J. (2013a): „Zavrženo: jazyk cenzury.“ Nebezpečná literatura? Antologie z myšlení o literární cenzuře, eds. T. Pavlíček, P. Píša \& M. Wögerbauer, Host, Brno, s. 83-102.

Butlerová, J. (2013b): „Analytika moci - rozhovor.“ A2 9 (19): 20-21. [online] dostupné z: <http://www.advojka.cz/archiv/2013/19/analytika-moci>.

Butlerová, J. (2016): „Bojujme za svět bikin i hidžábu.“ Lidové noviny 9. 4. 2016, s. 15.

Carruthers, S. (2011): The Media at War. Palgrave Macmillan, New York, NY.

Coates, A. (2006): „Culture, the Enemy and the Moral Restraint of War.“ In The Ethics of War: Shared Problems in Different Traditions, eds. R. Sorabji \& D. Rodin, Routledge New York, NY, s. 208-221.

Collins, S. Selfless Persons: Imagery and Thought in Theravada Buddhism. Cambridge University Press, Cambridge.

Culler, J. (2015): Krátký úvod do literární teorie. Host, Brno.

Čermák, I. (2003): „Agrese, osobnost a vztah k vlastnímu já.“ In Agrese, identita, osobnost, eds. I. Čermák, M. Hřebíčková \& P. Macek, Psychologický ústav Akademie věd ČR, Brno, s. 23-56.

Dearing, J. \& Rogers, E. (1996): Agenda-Setting. Sage Publications, Thousand Oaks, CA.

Derrida, J. (1978): Writing and Difference. Routledge, London.

Derrida, J. (1993): Texty k dekonstrukci. Archa, Bratislava.

Derrida, J. (1999): Gramatológia. Archa, Bratislava.

Derrida, J. (1999a): „Signature Event Context.“ In A Derrida Reader: Between the Blinds, ed. P. Kamuf, Columbia University Press, New York, NY, s. 80-111.

Dorman, W. (1997): „Press Theory and Journalistic Practice: The Case of Gulf War.“ In Do the Media Govern?, eds. S. Iyengar \& P. Reeves, Sage, Thousand Oaks, CA, 1997, s. 118-125.

Drulák, P. (2003): Teorie mezinárodních vztahủ. Portál, Praha. 
Dutton, D. (1998): The Bad Writing Contest Press Release. [online] dostupné z: <http://denisdutton.com/bad_writing.htm>

Easton, D. (1965): A Systems Analysis of Political Life. Wiley, New York, NY.

Ebert, T. (1995): „(Untimely) Critiques for a Red Feminism.“ In Post-ality: Marxism and Postmodernism, eds. M. Zavarzadeh, T. Ebert \& D. Morton, Maisonneuve Press, Washington, DC, 1995, s. 113-149. [online] dostupné z: <https://www.marxists.org/reference/subject/philosophy/works/us/ebert.htm>.

Ebert, T. (1996): Ludic Feminism and After: Postmodernism, Desire, and Labor in Late Capitalism. University of Michigan Press, Ann Arbor, MI.

Fafejta, M. (2001): „Pohlaví, rod a feministická politika - pokus o dekonstrukci pojmu přirozenost.“ Filosofický časopis 49 (5): 805-818.

Festinger, L. (1957): A Theory of Cognitive Dissonance. Stanford University Press, Stanford, CA.

Foucault, M. (1982): „The Subject and Power.“ In Michel Foucault: Beyond Structuralism and Hermeneutics, H. Dreyfus \& P. Rainow, , Chicago University Press, Chicago, IL, 1982, s. 208-226. [online] dostupné z: <http://foucault.info/documents/foucault.power.en.html>.

Foucault, M. (1999): Dějiny sexuality I: vůle k vědění. Herrman a synové, Praha.

Foucault, M. (2000): Dohlížet a trestat. Dauphin, Podlesí.

Foucault, M. (2002): Archeologie vědění. Herrman a synové, Podlesí.

Franklin, A. (1967): (You Make Me Feel Like) A Natural Woman - hudební skladba. . [online] dostupné z: <https://www.youtube.com/watch?v=rrOGrCBgv4c>.

Fred, A. (2006): Já a obranné mechanismy. Portál, Praha.

Freud, S. (1923): „The Ego and the Id.“ In The Standard Edition of the Complete Psychological Works of Sigmund Freud, ed. J. Strachey, Vol. 19. W. W. Norton and Company, New York, NY, 1961.

Freud, S. (2002): Spisy z let 1913-1917, svazek 10. Psychoanalytické nakladatelství, Praha.

Fulka, J. (2002): „Od interpelace k performativu (feminismus a konstrukce rodové identity).“ In Sborník prací FSS brněnské univerzity: sociální studia, 7, s. 29-50. [online] dostupné z: <http://socstudia.fss.muni.cz/dokumenty/080304142918.pdf>.

Fulka, J. (2013): „Úvod k textu Judith Butlerové - Svědomí z nás všech činí subjekty.“ Filosofický časopis 61 (2): 229-236.

Fulka, J. (2013a): „Za které životy netruchlíme?: k prvnímu českému vydání knihy Judith Butler.“'A2 9 (19): 26. [online] dostupné z: <http://www.advojka.cz/archiv/2013/19/za-ktere-zivoty-netruchlime>. 
Geist, B. (2000): Psychologický slovník. Vodnáŕ, Praha.

Giles, D. (2012): Psychologie médií. Grada, Praha.

Goffman, E. (1974): Frame Analysis. An Essay on the Organization of Experience. Penguin Books, Harmondsworth.

Górská, M. \& Matonoha, J. (2008): „Popis mnoha zápasů: diskurz, subjekt a moc v myšlení Judith Butlerové.“ Česká literatura: časopis pro literární vědu 56 (6): 805-829.

Greene, J. (2013): Moral Tribes: Emotion, Reason, and the Gap Between Us and Them. Penguin Books, New York, NY.

Grimaldi, N. (2013): Nelidskost. Academia, Praha.

Haidt, J. (2012): The Righteous Mind: Why Good People are Divided by Politics and Religion. Pantheon, New York, NY.

Hallin, D. (1989): The Uncensored War: The Media and Vietnam. University of California Press, Berkeley, CA.

Hammond, W. (1998): Reporting Vietnam: Media and Military at War. University Press of Kansas, Lawrence, KS.

Hartmann, H. (1958): Ego Psychology and the Problem of Adaptation. International Universities Press, New York, NY.

Hasselton, M., Nettle, D. \& Andrews, P. (2005): „The Evolution of Cognitive Bias.“ In Handbook of Evolutionary Psychology, ed. D. M. Buss, Wiley, Hoboken, NJ, s. 724-746.

Hawkesworth, M. (2006): Feminist Inquiry: From Political Conviction to Methodological Innovation. Rutgers University Press New, Brunswick, NJ.

Heczková, L. (2013): „Nutnost oplakávat nepř́tele.“ A2 9 (19): 20-21. [online] dostupné z: <http://www.advojka.cz/archiv/2013/19/nutnost-oplakavat-nepritele>.

Hennessy, R. (1995): „Queer Visibility in Commodity Culture.“ In Postmodernism: Beyond Identity Politics, eds. L. Nicholson \& S. Seidman, Cambridge University Press, Cambridge.

Herz, J. (1950): „Idealist Internationalism and the Security Dilemma.“ World Politics 2 (2): 157-180.

Herz, J. (1951): Political Realism and Political Idealism. Chicago University Press, Chicago, IL.

Hobbes, T. (2009): Leviathan. Oikoymenh, Praha.

Holzgrefe, J. L. \& Keohane, R. (eds.). (2003): Humanitarian Intervention: Ethical, Legal and Political Dilemmas. Cambridge University Press, Cambridge.

Hoskins, A. \& O’loughlin, B. (2010): War and Media. Polity Press, Malden, MA. 
Hutchinson, W. (2006): „Information Warfare and Deception.“ Informing Science 6. Informing Science Institute, Santa Rosa, CA, s. 213-223. [online] dostupné z: <http://www.inform.nu/Articles/Vo19/v9p213-223Hutchinson64.pdf>.

Ignatieff, M. (2001): Virtuální válka. Themis, Praha.

Jacobson, E. (1964): The Self and the Object World. International Universities Press, New York, NY.

Kahneman, D. \& Tversky, A. (1984): „Choices, Values, and Frames.“ American Psychologist 28: 107-128.

Kalvas, F. (2009): Nastolování agendy: role masové a interpersonální komunikace, osobní zkušenosti a genderu. ZČU, Plzeň.

Kalvas, F., Váně, J., Štípková, M. \& Kreidl, M. (2012): „Rámcování a nastolování agendy: dva paralelní procesy v interakci.“ Sociologický časopis 48 (1): 3-37. [online] dostupné z: $<$ http://sreview.soc.cas.cz/uploads/99442ea63836874d8cc54a132363c58004f9424 5_R\%C3\%A1mcov\%C3\%A1n\%C3\%AD\%20a\%20nastolov\%C3\%A1n\%C3\%A D\%20agendy.pdf $>$.

Kiczková, Z. (2007): „Subjekt - Moc - Rod: Kritické inšpirácie Judith Butler.“In Vztahy, jazyky, těla: texty z 1. konference českých a slovenských feministických studii, L. Heczková et al., FHS UK, Praha, s. 37-51.

Kratochvíl, P. \& Drulák, P. (eds.) (2009): Encyklopedie mezinárodních vztahů. Portál, Praha.

Lazarsfed, P. F., Berelson, B. \& Gaudet, H. (1944): The People's Choice: How the Voter Makes up his Mind in a Presidential Campaign. Duell-Sloan and Pearce, New York, NY.

Lecky, W. E. H. (2007): The History of European Morals from Augustus to Charlemagne. Gardners Books, Eastbourne.

Lewin, K. Z. (1943): „Forces Behind Food Habits and Methods of Change.“ In Bulletin of the National Research Council, 108, s. 35-65.

Lewis, J. et al. (2006): Shoot First and Ask Questions Later: Media Coverage of the 2003 Iraq War. Peter Lang, New York, NY.

Lévinas, E. (1994): Nine Talmudic Readings. Indiana University Press, Bloomington.

Lévinas, E. (1997): Totalita a nekonečno: esej o exterioritě. Oikoymenh, Praha.

Lévinas, E. (1998): Otherwise Than Being or Beyond Essence. Duquesne University Press, Pittsburgh, PE.

Lévinas, E. (2006): „Useless Suffering.“ In Entre Nous: Thinking of the Other. Continuum, London, s. 78-87.

Lévinas, E. (2009): Etika a nekonečno. Oikoymenh, Praha. 
Linebarger, P. (1954): Psychological Warfare. Duell, Sloan and Pearce, New York, NY.

Lišková, K. (2009): Hodné holky se dívají jinam: feminismus a pornografie. SLON, Praha.

Llewelyn, J. (1995): Emmanuel Levinas: The Genealogy of Ethics. Routledge, London.

Luhmann, N. (2014): Realita masmédií. Academia, Praha.

Matonoha, J. (2010): „Pasti performativity: dělat, jako by se nic nedělo.“ In Performance/performativita, ed. O. Sládek, Ústav pro českou literaturu AV ČR, Praha, s. 21-34.

McGrath, L. (2009): „Frames of War: When is Life Grievable? (review).“ Comparative Literature Issue 124 (5): 1232-1236. [online] dostupné z: <https://muse.jhu.edu/journals/mln/summary/v124/124.5.mcgrath.html>.

McCombs, M. (2009): Agenda setting - nastolování agendy: masová média a veřejné mínění. Portál, Praha.

McCombs, M. \& Shaw, D. (1972): „The Agenda-Setting Function of Mass Media.“ Public Opinion Quarterly 36: 176-187.

McQuail, D. (2009): Úvod do teorie masové komunikace. Portál, Praha.

McRobbie, A. (2006): Aktuální témata kulturálních studií. Portál, Praha.

McRobbie, A. (2009): „Book of the Week: Frames of War.“ In Times Higher Education (June 25). [online] dostupné z:

<https://www.timeshighereducation.com/books/book-of-the-week-frames-ofwar/407098.article>.

Mikšík, O. (2007): Psychologické teorie osobnosti. Karolinum, Praha.

Mill, J. S. (1859): „A Few Words on Non-intervention.“ Fraser’s Magazine

(December), s. 766-776. [online] dostupné z:

<http://www.libertarian.co.uk/lapubs/forep/forep008.pdf>

Miller, D., ed. (2003): Tell Me Lies: Propaganda and Media Distortion in the Attack on Iraq. Pluto Press, London.

Moseley, A. (2011): „The Just War Theory.“ In Internet Encyclopedia of Philosophy. [online] dostupné z: <http://www.iep.utm.edu/justwar/>.

Murray, W. \& Mansoor, P. (2012): Hybrid Warfare: Fighting Complex Opponents from the Ancient World to the Present. Cambridge University Press, Cambridge.

Nagl-Docekal, H. (2007): Feministická filozofie: výsledky, problémy, perspektivy. SLON, Praha.

Neff, S. (2014): Justice Among Nations: A History of International Law. Harvard University Press, Boston, MA.

Nelson, L. (1999): „Bodies (and Spaces) Do Matter: The Limits of Performativity.“ Gender, Place and Culture 6 (4): 331-354. 
Noelle-Neumann, E. (1984): The Spiral of Silence. A Theory of Public Opinion - Our Social Skin. University of Chicago Press, Chicago, IL.

Nussbaum, M. (1999): „The Professor of Parody: The Hip Defeatism of Judith

Butler.“ New Republic (February 22): 37-45. [online] dostupné z:

$<$ http://faculty.georgetown.edu/irvinem/theory/Nussbaum-Butler-Critique-NR-299.pdf $>$.

Obama, B. (2009): „Statement by the President on the Situation in Sri Lanka and Detainee Photographs.“ In The White House Office of the Press Secretary (13. května). [online] dostupné z: 〈https://www.whitehouse.gov/the-pressoffice/statement-president-situation-sri-lanka-and-detainee-photographs>

Orend, B. (2008): „War.“ In The Stanford Encyclopedia of Philosophy. [online] dostupné z: 〈http://plato.stanford.edu/archives/fall2008/entries/war/>.

Pach, C. (2010): „“Our Worst Enemy Seems to Be the Press”: TV News, the Nixon Administration, and U.S. Troop Withdrawal from Vietnam, 1969-1973.“ Diplomatic History 34 (3): 555-565.

Parker, G. (1994): „Early Modern Europe.“ In The Laws of War: Constraints on Warfare in the Western World, eds. M. Howard, G. Andreopoulos \& M. Shulman, Yale University Press, New Haven, CT.

Peperzak, A. T. (2005): To the Other: An Introduction to the Philosophy of Emmanuel Levinas. Purdue University Press, Lafayette, IN.

Pinker, S. (2002): The Blank Slate: Modern Denial of Human Nature. Penguin Books, New York, NY.

Platon (1997): Zákony. Oikoymenh, Praha.

Platon (2014): Ústava. Oikoymenh, Praha.

Pňačeková, M. (2010): „De/konstrukce genderové identity v dramatickém diskurzu.“ In Performance/performativita, ed. O. Sládek, Ústav pro českou literaturu AV ČR, Praha, s. 171-183.

Poole, S. (2009): „Frames of War: Frames of War: When is Life Grievable?“ The Guardian (May 9). [online] dostupné z: <http://www.theguardian.com/books/2009/may/09/judith-butler-frames-of-war>.

Ptáčníková, I. (2015): „Judith Butlerová: Rámce války: Za které životy netruchlíme?““ Mezinárodní vztahy 50 (4): 67-71.

Quine, W. V. O. (1992): Pursuit of Truth. Harvard University Press, Boston, MA.

Quine, W. V. O. (1995): „Dvě dogmata empirismu.“ In Co je analytický výrok?, eds. J. Peregrin \& S. Sousedík, Oikoymenh, Praha, s. 79-99.

Reese, S. et al. (2003): Framing Public Life: Perspectives on Media and Our

Understanding of the Social World. Lawrence Erlbaum Associates Publisher, 
Mahwah, NJ. [online] dostupné z:

$<$ https://journalism.utexas.edu/sites/journalism.utexas.edu/files/attachments/reese/ framing-public-life.pdf $>$.

Reese, S. \& Lewis, S. (2009): „Framing the War on Terror: The Internalization of Policy in the US Press.“ Journalism 10 (6): 777-797. [online] dostupné z: $<$ https://journalism.utexas.edu/sites/journalism.utexas.edu/files/attachments/reese/ framing-war-on-terror-sagepub.pdf $>$

Report of the International Committee of the Red Cross (ICRC) on the Treatment by the Coalition Forces of Prisoners of War and Other Protected Persons by the Geneva Conventions in Iraq During Arrest, Internment and Interrogation. 2004. [online] dostupné z: <http://www.derechos.org/nizkor/us/doc/icrc-prisoner-report-feb2004.pdf>.

Rorty, R. (1991): Objectivity, Relativism, and Truth. Cambridge University Press, Cambridge.

Rorty, R. (2012): Filosofie a zrcadlo př́rody. Academia, Praha.

Rousseau, J. J. (1978): Rozpravy. Svoboda, Praha.

Rowe, M. (2010): „Judith Butler: War Empathizer.“ In Utne Reader (NovemberDecember). [online] dostupné z: 〈http://www.utne.com/politics/utne-readervisionaries-judith-butler-abu-ghraib-torture.aspx $>$.

Salih, S. (2002): Judith Butler. Routledge, New York, NY.

Shoemaker, P \& Vos, T. (2009): Gatekeeping Theory. Routledge, New York.

Shue, H. (2008): „Omezená suverenita.“ Filosofický časopis 56 (6): 811-832.

Schwartzman, L. (2002): „Hate Speech, Illocution, and Social Context: A Critique of Judith Butler.“ Journal of Social Philosophy 33 (3): 421-441.

Singer, P. (1997): „The Drowning Child and the Expanding Circle.“ New Internationalist (April), [online] dostupné $\mathrm{z}$ : <http://www.utilitarian.net/singer/by/199704--.htm>.

Singer, P. (2011): The Expanding Circle: Ethics, Evolution, and Moral Progress. Princeton University Press, Princeton, NJ.

Smith, D. (1999): „When Ideas Get Lost in Bad Writing; Attacks on Scholars Include a Barbed Contest With 'Prizes'.“ The New York Times, 27. února. [online] dostupné z: <http://www.nytimes.com/1999/02/27/arts/when-ideas-get-lost-bad-writingattacks-scholars-include-barbed-contest-with.html?pagewanted=all $>$.

Sokolová, V. (2003): „Moje tělo je ONA.” Souvislosti: revue pro literaturu a kulturu 14 (4): 80-94.

Sontagová, S. (2011): S bolestí druhých před očima. Paseka, Praha. 
Sumner, W. G. (1906): Folkways: A Study of the Sociological Importance of Usages, Manners, Customs, Mores, and Morals. Ginn and Company, New York, NY.

Šmejkalová-Strickland, J. (1992): „Potíže s rodem. Drobné poznámky k jedné knize.“ Filosofický časopis 40 (5): 819-824.

Tahmasebi-Birgani, V. (2014): Emmanuel Levinas and the Politics of Non-Violence. University of Toronto Press, Toronto.

Tajfel, H. (1974): „Social Identity and Intergroup Behaviour.“ Social Science Information (April), 13, s. 65-93.

Tajfel, H. (1979): „Individuals and Groups in Social Psychology.“ British Journal of Social and Clinical Psychology 18: 183-190.

Tajfel, H. \& Turner, J. (1986): „The Social Identity Theory of Intergroup Behaviour.“ In Psychology of Intergroup Relations, eds. S. Worchel \& W. G. Austin, NelsonHall, Chicago, IL, s. 7-24.

Taylor, P. (1998): War and the Media: Propaganda and Persuasion in the Gulf War. Manchester University Press, Manchester.

Tilly, C. (2003): The Politics of Collective Violence. Cambridge University Press, Cambridge.

Trampota, T. (2006): Zpravodajství. Portál, Praha.

Trianidis, H. (2000): „Allocentrism-Idiocentrism.“ In Encyclopedia of Psychology, ed. A. Kazdin, American Psychological Association, Washington, D.C., s. 118-119.

Tuck, R. (2001): The Rights of War and Peace: Political Thought and the International Order from Grotius to Kant. Oxford University Press, Oxford.

Tumber, H. \& Palmer, J. (2004): Media at War: the Iraq Crisis. Sage, London.

Tversky, A. \& Kahneman, D. (1981): „The Framing of Decisions and the Psychology of Choice." Science 211 (4481): 453-458.

Ventre, D. (ed.). (2011): Cyberwar and Information Warfare. Wiley, Hoboken, NJ.

Vodrážka, M. (2007): deCivilizace. Pavel Mervart, Červený Kostelec.

Volek, J. (2002): „Média v omezené válce: Simulovaný konflikt v Perském zálivu.“ Revue pro média, č. 2. Katedra mediálních studií a žurnalistiky FSS, Brno, s. 110. [online] dostupné $\mathrm{z}$ :

<http://rpm.fss.muni.cz/Revue/Revue02/volek_mediavomezenevalce.pdf〉.

Waisová, Š. (2009): Úvod do studia mezinárodních vztahů. Aleš Čeněk, Plzeň.

Watkins, T. L. (2010): „Judith Butler, Frames of War.“ Rhizomes 20 (Summer). [online] dostupné z: <http://www.rhizomes.net/issue20/reviews/watkins.html>.

Williams, P. \& Tribe, A. (2011): Buddhistické myšlení: úplné uvedení do indické tradice. ExOriente, Praha. 
Withers, D. (2010): „Knowing the Frame.“ Women: A Cultural Review 21 (2): 227229.

Wytt, C. (1995): Paper Soldiers: The American Press and the Vietnam War. University of Chicago Press, Chicago, IL.

Zábrodská, K. (2009): Variace na gender: poststrukturalismus, diskursivní analýza a genderová identita. Academia, Praha.

Ženevské úmluvy a dodatkové protokoly. (2005): Český červený kříž, Praha.

Elektronická podoba aktualizována ke dni 1. 3. 2016. [online] dostupné z: <http://www.cervenykriz.eu/cz/mhp/konvence.htm>.

Žižek, S. (2007): Nepolapitelný subjekt: chybějící střed politické ontologie. L. Marek, Chomutov. 